\title{
Geological history of the Pieniny Klippen Belt and Middle Jurassic black shales as one of the oldest deposits of this region - stratigraphical position and palaeoenvironmental significance
}

\author{
Geologiczna historia pienińskiego pasa skałkowego a środkowojurajskie czarne \\ łupki jako jedne z najstarszych utworów regionu - stratygraficzna pozycja \\ i paleośrodowiskowe znaczenie \\ Michał Krobicki \& Jan Golonka \\ AGH University of Science and Technology, Faculty of Geology, Geophysics and Environmental Protection, \\ Al. Mickiewicza 30, 30-059 Kraków \\ e-mail:krobicki@geol.agh.edu.pl,jan_golonka@yahoo.com
}
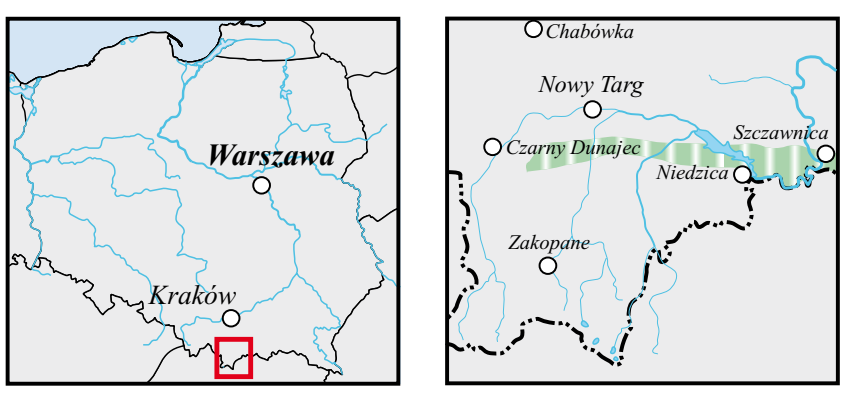

Abstract: The main aim of this paper is presentation both
general history of the Pieniny Klippen Belt and two famous
sites in this region: Dunajec River Gorge and Homole Gorge.
According to such general introduction the authors explain also
palaeogeographical position of the Pieniny Klippen Belt Basin
within Mesozoic Tethyan Ocean, and especially stratigraphical
position and palaeoenvironmental conditions of Middle Jurassic
black shales and their significance in geodynamic reconstruction
of this basin. Both the Dunajec River Gorge, one of the most
popular geotouristic object within Pieniny Mts, and Homole
Gorge, one of the best place to geological study of the Pieniny
Klippen Belt, are most attractive natural phenomena of this
geological region. Key words: southern Poland, Carpathians, Pieniny Mts, Pieniny Klippen Belt, black shales, Mesozoic history

Treść: Głównym celem niniejszej pracy jest prezentacja zarówno generalnej historii pienińskiego pasa skałkowego jak i dwóch stynnych miejsc tego regionu: przełomu Dunajca $i$ wqwozu Homole. W nawiqzaniu do takiego generalnego wprowadzenia autorzy przedstawiaja również paleogeograficznq pozycję basenu pienińskiego pasa skałkowego w obrębie mezozoicznego oceanu Tetydy, a szczególnie stratygraficzna pozycję i paleośrodowiskowe warunki powstawania środkowojurajskich czarnych tupków oraz ich znaczenie w geodynamicznych rekonstrukcjach tego basenu. Zarówno splyw Dunajcem, jeden z najbardziej popularnych obiektów geoturystycznych w Pieninach, jak i wawóz Homole, jedno z najlepszych miejsc do studiowania geologii pienińskiej, sq najbardziej atrakcyjnymi obiektami przyrodniczymi $w$ tym regionie geologicznym.

Słowa kluczowe: poludniowa Polska, Karpaty, Pieniny, pieniński pas skatkowy, czarne tupki, mezozoik

\section{Introduction}

The Outer Carpathians and Pieniny Klippen Belt realm form the northernmost part of the Polish Carpathians. The Outer (Flysch) Carpathians are composed of Jurassic to Early Miocene flysch sequences (Ślączka, 1996; Oszczypko, 2004, 2006a, b; Oszczypko et al., 2005, 2006). These deposits were folded and overthrust during the Miocene times (Alpine orogeny), forming north-verging nappes detached from their original basement (Ślączka, 1996). All Outer Carpathians nappes are thrusting over the East European Platform covered by Miocene deposits of the Carpathian Foredeep (Figs $1,2)$. These nappes have allochthonous character. The deposits included in the nappes originated in basins situated outside their present location. The Pieniny Klippen Belt (PKB) is situated at the boundary between Outer Flysch Carpathians and Inner Carpathians forming strongly tectonized terrain about $600 \mathrm{~km}$ long and 1-20 km wide, which stretches from Vienna to the West up to Romania to the East (Fig. 1). Present

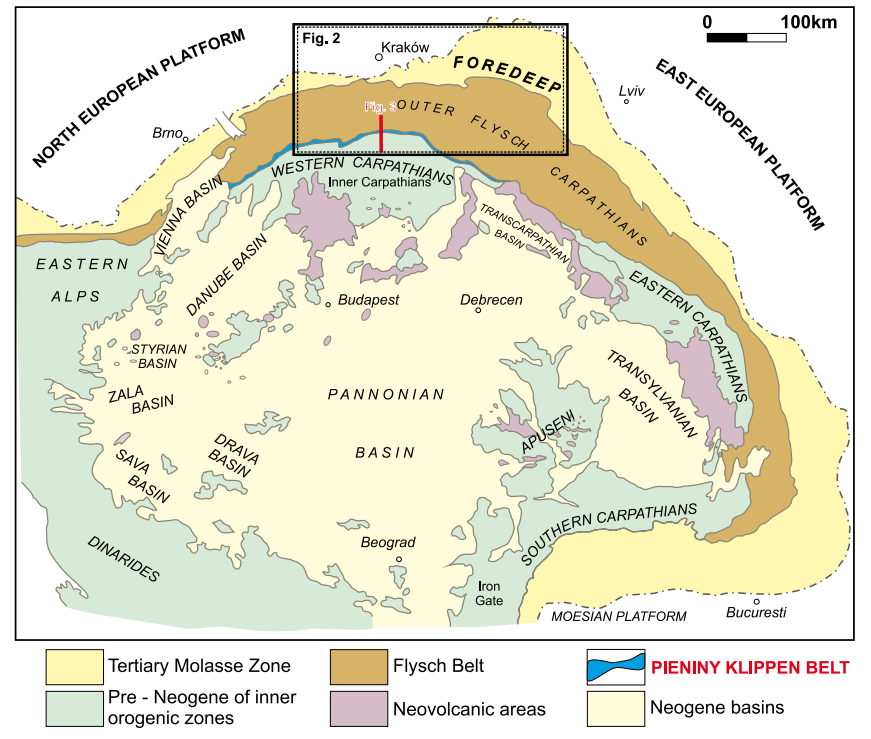

Fig. 1. Tectonic sketch map of the Alpine-Carpathian-PannonianDinaride basin system (modified after Kováč et al., 1998; Plašienka et al., 2000) • Szkic tektoniczny regionu alpejsko-karpacko-panońsko-dynarydzkiego (zmodyfikowano według Kováč et al., 1998; Plašienka et al., 2000) 


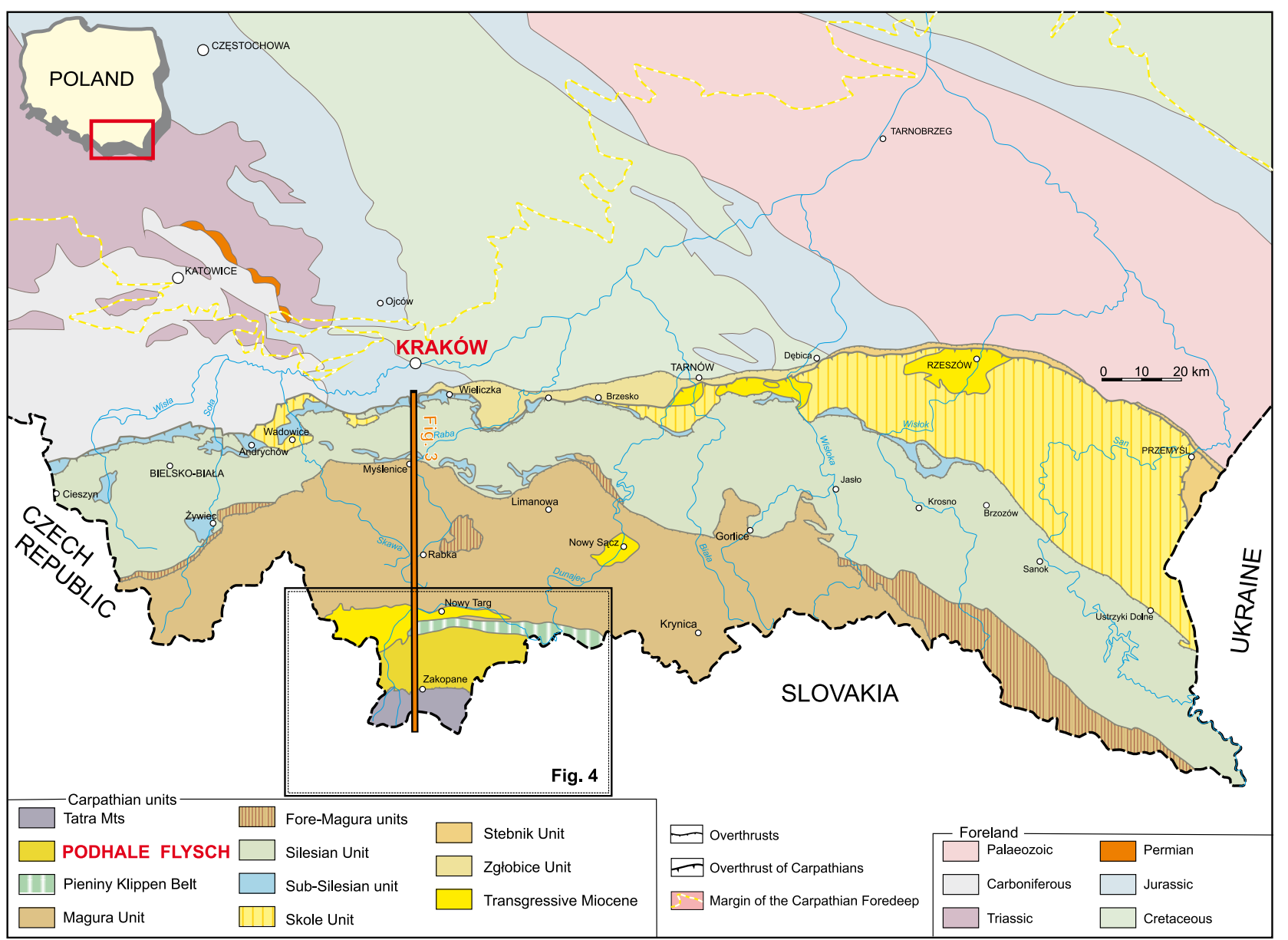

Fig. 2. Geological map of the Polish Carpathians, Carpathian Foredeep and Foreland (after Żytko et al., 1989; Golonka et al., 2006; simplified) with location both of the field trip (rectangle - Fig. 9) and of general cross-section across Carpathians (Fig. 3) • Mapa geologiczna polskich Karpat, Zapadliska Przedkarpackiego i ich przedpola (wg Żytko et al., 1989; Golonka et al., 2006; uproszczono) z lokalizacją zarówno wycieczki terenowej (prostokąt - Fig. 9) jak i generalnego przekroju przez Karpaty (Fig. 3)

day confines of the PKB are strictly tectonic. They may be characterized as (sub)vertical faults and shear zones (Fig. 3), along which a strong reduction of space of the original sedimentary basins took place (Birkenmajer, 1986; Golonka \& Krobicki, 2006; Krobicki \& Golonka, 2006). The PKB tectonic components of different age, strike-slip, thrust as well as toe-thrusts and olistostromes were mixed together, giving the present-day melange character of the PKB, where individual tectonic units are hard to distinguish.

\section{General history of the Pieniny Klippen Belt Basin}

Palinspastic reconstruction of the PKB Basin indicates occurrence of submarine ridge during the whole Jurassic and Cretaceous times. This so-called Czorsztyn Ridge, an elongated structure, subdivided Pieniny and Magura basins within the Carpathian part of the northernmost Tethyan Ocean (Figs 4-6) (comp. Golonka, 2004, 2007a, b with references cited therein). Its SW-NE orientation and location within the Tethyan Ocean is interpreted by means of palaeomagnetic data, relationship of sedimentary sequences and palaeoclimate (see discussion in Golonka \& Krobicki 2001 see also Aubrecht \& Túnyi, 2001; Lewandowski et al., 2005; Grabowski et al., 2008). The basins divided by the
Czorsztyn Ridge were dominated by a pelagic type of sedimentation. The deepest part of the PKB Basin is well documented by deep water Jurassic-Early Cretaceous deposits (radiolarites and pelagic Maiolica-type cherty limestones) (Birkenmajer, 1979, 1986; Golonka \& Sikora 1981; Golonka \& Krobicki, 2004; Krobicki et al., 2006) of the so-called Branisko and Pieniny successions. The transitional, shallower sequences, which primary occupied slope between deepest basinal units and the Czorsztyn Ridge are known as Czertezik and Niedzica successions, and the shallowest zone is Czorsztyn Succession which primary occupied SE slope of the Czorsztyn Ridge (Birkenmajer, 1986; Golonka \& Krobicki, 2004; Krobicki \& Golonka, 2006) (Figs 6, 7).

The earliest stage of the basin history is enigmatic and documented only by Triassic pebbles in the CretaceousPalaeogene flysch. These pebbles indicate the possibility of an existence of enigmatic embayment of the Vardar-Transilvanian Ocean which separated the Tisa (Bihor-Apuseni) block from the Moesian Eastern European Platform (Săndulescu, 1988; Golonka \& Krobicki, 2004). The other interpretation of these pebbles origin involves the rotation of the Inner Carpathian plate (Golonka, 2005). The oldest Jurassic rocks (Hettangian/Sinemurian in age) of the Pieniny Klippen Belt are preserved only in the Slovakian and Ukrainian part of the region. They consist of different clastic deposits with limestone 


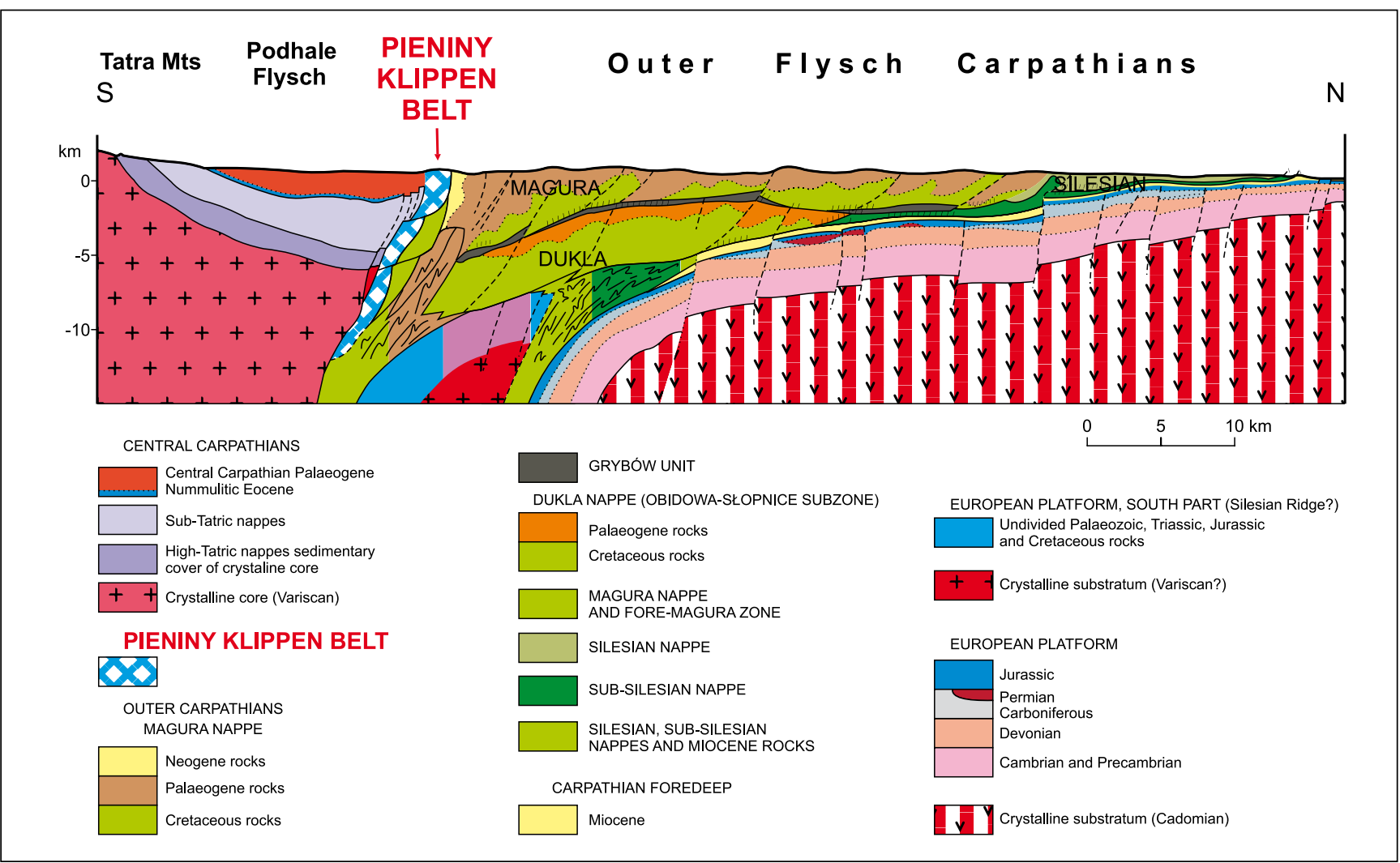

Fig. 3. Generalized cross-section across Polish Carpathians (after Golonka et al., 2006) • Zgeneralizowany przekrój przez polskie Karpaty (wg Golonka et al., 2006)

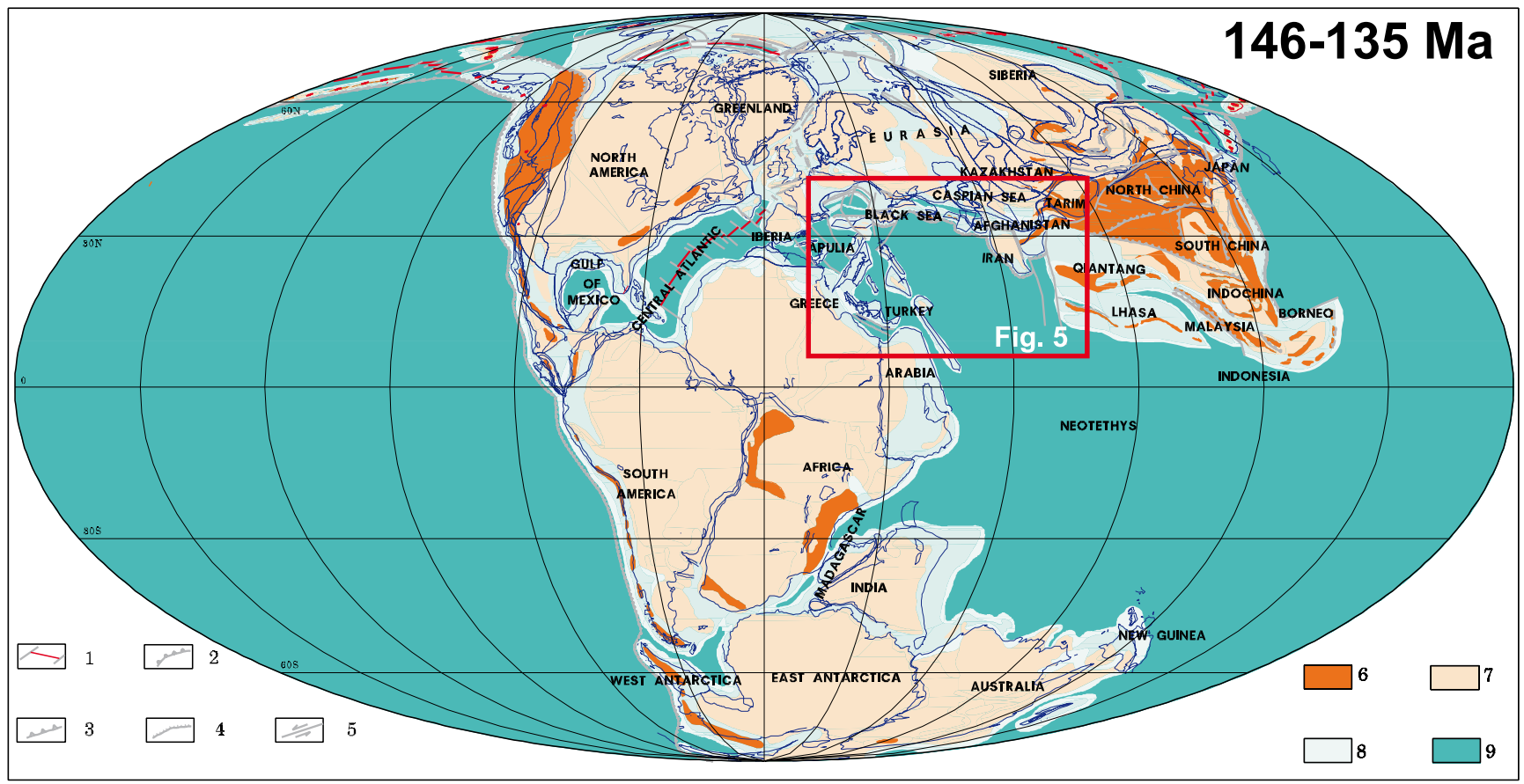

Fig. 4. Global plate tectonic map of latest Jurassic-earliest Cretaceous. Explanations: 1 - oceanic spreading center and transform faults; 2 - subduction zone; 3 - thrust fault; 4 - normal fault; 5 -transform fault; 6 - mountains; 7 - landmass; 8 - shallow sea and slope; 9 - deep ocean basin (from Golonka, 2000; modified) - Globalna mapa tektoniki płyt litosfery w napóźniejszej jurze-najwcześniejszej kredzie. Objaśnienia: 1 - centra spredingu oceanicznego i uskoki transformujące; 2 - strefa subdukcji; 3 - uskoki nasuwcze; 4 - uskoki normalne; 5 - uskoki transformujące; 6 - góry; 7 - lądy; 8 - płytkie morza i skłon kontynentalny; 9 - głębokie oceany (wg Golonka, 2000; zmienione)

intercalations of Gresten-like dark/black facies (Schlögl et al., 2004 with literature). However, Toarcian-Lower Bajocian Bositra ("Posidonia") black shales with spherosiderites (Skrzypny Shale Formation in local, formal nomenclature, see Birkenmajer, 1977; see Fig. 7), which we will see in Homole Gorge, last stop, as well as dark marls and spotty limestones of widespread Tethyan Fleckenkalk/Fleckenmergel facies, indicate the oxygen-depleted conditions (Birkenmajer, 


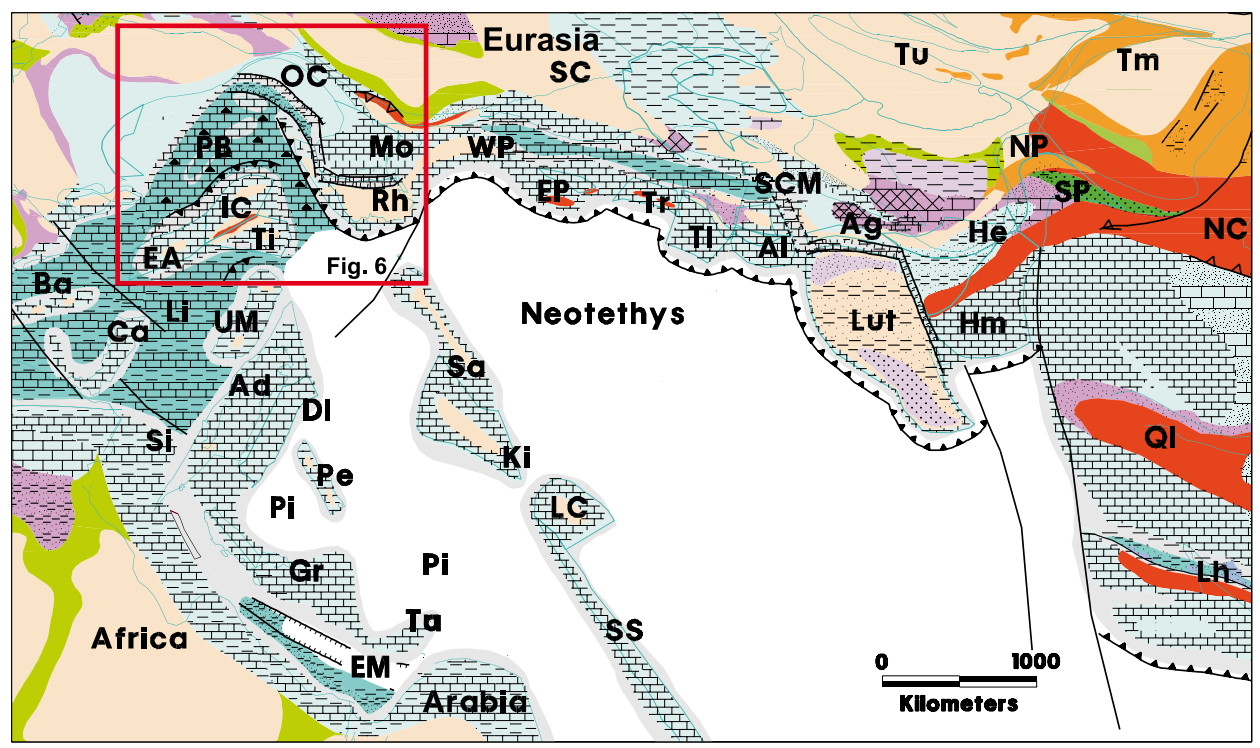

Fig. 5. Plate tectonic, palaeoenvironment and lithofacies map of the western Tethys, future Central Atlantic and adjacent areas during latest Jurassic-earliest Cretaceous time (after Golonka, 2007a; modified). Abbreviations of oceans and plates names: Ad - Adria (Apulia); Ag - Aghdarband (southern Kopet Dagh); Al - Alborz; Ba - Balearic; Ca - Calabria-Campania; Di - Dinarides; EA -Eastern Alps; EM - Eastern Mediterranean; EP - Eastern Pontides; Gr - Greece; He - Heart; Hm - Helmand; IC - Inner Carpathians; Ki - Kirsehir; LC - Lesser Caucasus; Lh - Lhasa; Li - Ligurian (Piemont) Ocean; Mo - Moesia; NC - North China; NP - North Pamir; OC - Outer Carpathians; PB - Pieniny Klippen Belt Basin; Pe - Pelagonian plate; Pi - Pindos Ocean; Qi - Qiangtang; Rh - Rhodopes; Sa - Sakarya; SC - Scythian; SCM - South Caspian microcontinent; S1 - Sicily; SP - South Pamir; SS - Sanandaj-Sirjan; Ta - Taurus terrane; Ti - Tisa; Tl - Talysh; Tm - Tarim; Tr - Transcaucasus; Tu - Turan; UM - Umbria-Marche; WP - Western Pontides

Mapa tektoniki płyt, paleośrodowiska i litofacji zachodniej Tetydy, przyszłego centralnego Atlantyku i obszarów sąsiednich w najpóźniejszej jurze-najwcześniejszej kredzie (wg Golonka, 2007; zmienione). Objaśnienia skrótów: Ad - Adria (Apulia); Ag - Aghdarband (południowy Kopet Dagh); Al - Alborz; Ba - Baleary; Ca - Kalabria-Kampania; Di - Dynarydy; EA - wschodnie Alpy; EM - wschodni obszar medyterrański; EP - wschodnie Pontydy; Gr - Grecja; He - Heart; Hm - Helmand; IC - Karpaty Wewnętrzne; Ki - Kirsehir; LC - Kaukaz Mniejszy; Lh - Lhasa; Li - ocean liguryjski (piemoncki); Mo - płyta mezyjska; NC - Chiny północne; NP - Pamir północny; OC - Karpaty Zewnętrzne; PB - basen pienińskiego pasa skałkowego; Pe - płyta pelagońska; Pi - ocean Pindos; Qi - Qiangtang; Rh - Rodopy; Sa - Sakarya; SC - płyta scytyjska; SCM - mikrokontynent południowego Morza Kaspijskiego; Sl - Sycylia; SP - Pamir południowy; SS - Sanandaj-Sirjan; Ta - terran Gór Taurus; Ti - płyta Cisy; Tl - Talysh; Tm - Tarim; Tr - obszar transkaukaski; Tu - Turan; UM - Umbria-Marche; WP - Pontides Zachodnie.

Objaśnienia legendy: 1 - góry/wyżyny (aktywne tektonicznie); 2 - wyniesienia nieaktywne tektonicznie; 3 - niziny nieaktywne tektonicznie, bez osadów; 4-17 - środowiska sedymentacji [4 - lądowe nierozdzielne; 5 - rzeczne; 6 - rzeczno-jeziorne; 7 -jeziorne; 8 - eoliczne; 9 - przybrzeżne, przejściowe; 10 - paraliczne; 11 - międzypływowe; 12 - deltowe; 13 - płytkomorskie, szelfowe; 14 - skłonu kontynentalnego; 15 - głębokie oceany z sedymentacją (ze skorupą kontynentalną, przejściową lub oceaniczną); 16 - osady grawitacyjne (loby, spływy, turbidyty); 17 - głębokie oceany bez sedymentacji]; 18 - zlepieniec; 19 - piaskowiec, mułowiec; 20 - iły, łupki, mułowce; 21 - biogeniczne osady krzemionkowe; 22 - wapień; 23 - dolomit; 24 - kreda; 25 - ewaporaty nierozdzielone; 26 - piasek i łupek; 27 - węglany i łupki; 28 - piaski i węglany; 29 - węglany i ewaporaty; 30 - utwory intruzyjne; 31 - utwory ekstruzyjne; 32 - centra spredingu oceanicznego i uskoki transformujące; 33 - nieaktywne grzbiety spredingu; 34 - aktywna subdukcja; 35 - uskok normalny; 36 - nasunięcie; 37 - uskok przesuwczy; 38 - dzisiejsza linia brzegu; 39 - wulkanizm ekstensyjny lub gorących plamek; 40 - wulkanizm subdukcyjny; 41 - wulkanizm nieokreślony; 42 - rafa; 43 - łupki bogate w substancję organiczną

1986; Tyszka, 1994, 2001). One of the most rapidly change of sedimentation/palaeoenvironments within the PKB basins took place during late Early Bajocian when well-oxygenated multicoloured crinoidal limestones replaced dark and black sedimentation. The origin of the above mentioned Czorsztyn Ridge was connected with this Bajocian postrift geotectonic reorganization (Golonka et al., 2003; Krobicki, 2006). Sedimentation of younger (deposition since latest Bajocian) red nodular Ammonitico Rosso-type limestones was an effect of Meso-Cimmerian vertical movements which subsided Czorsztyn Ridge (Birkenmajer, 1986; Krobicki, 2006; Krobicki \& Golonka, 2006). In the same time first episode of radiolarite 


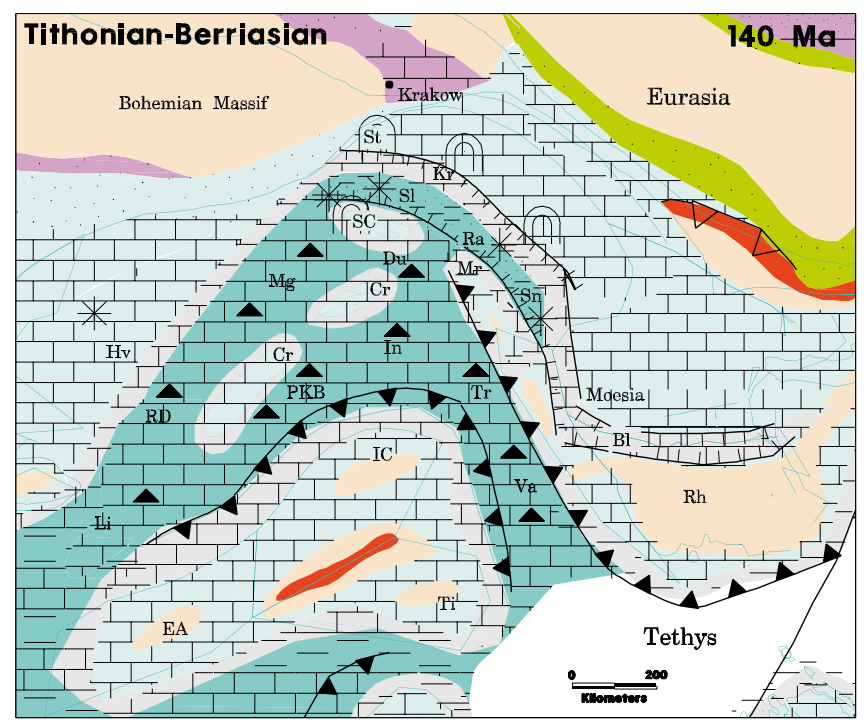

Fig. 6. Palaeoenvironment and lithofacies of the circum-Carpathian area during latest Jurassic-earliest Cretaceous; plates position at 140 $\mathrm{Ma}$ (modified from Golonka et al., 2006). Abbreviations: Bl-Balkan rift; Cr - Czorsztyn Ridge; Du - Dukla Basin; EA - Eastern Alps; Hv - Helvetic shelf; IC - Inner Carpathians; In - Inačovce-Kričevo zone; $\mathrm{Kr}$-Kruhel Klippe; Li - Ligurian Ocean; Mg - Magura Basin; $\mathrm{Mr}$ - Marmarosh Massif; PKB - Pieniny Klippen Belt Basin; Ra - Rakhiv Basin; RD - Rheno Danubian Basin; Rh - Rhodopes; SC - Silesian Ridge (Cordillera); Sl - Silesian Basin; Sn - Sinaia Basin; St - Štramberk Klippe; Ti - Tisa plate; $\mathrm{Tr}$ - Transilvanian Ocean; Va - Vardar Ocean. Explanations of colors and symbols - see Fig. 5

Mapa palinspastyczna z typowymi litofacjami obszaru wokół-karpackiego w najpóźniejszej jurze-najwcześniejszej kredzie; pozycja płyt litosfery $140 \mathrm{mln}$ lat temu (wg Golonka et al., 2006; zmodyfikowane) Skróty: Bl - ryft bałkański; Cr-grzbiet czorsztyński; Du - basen dukielski; EA -Alpy Wschodnie; Hv - szelf helwecki; IC - Karpaty Wewnętrzne; In - strefa Inačovce-Kričevo; $\mathrm{Kr}$ - Kruhel; $\mathrm{Li}$ - ocean liguryjski; $\mathrm{Mg}$ - basen magurski; $\mathrm{Mr}$ - masyw marmaroski; PKB - basen pienińskiego pasa skałkowego; $\mathrm{Ra}$ - basen rachowski, RD - basen renodunajski; Rh - Rodopy; SC - kordyliera śląska, Sl - basen śląski; Sn - basen Sinaia; St - Štramberk; Ti - płyta Cisy; $\mathrm{Tr}$ - ocean transylwański; Va - ocean Vardaru. Objaśnienia kolorów i szrafur - patrz Fig. 5

sedimentation took place in the axial, basinal sequences (Birkenmajer, 1977, 1986; Mišík, 1999). This episode marked beginning of the great facial differentiation between deepest and shallowest successions. The main phase of this facies differentiation involving, among the others, mixed siliceouscarbonate sedimentation took place later, mainly during Oxfordian times. Oxfordian radiolarites are typical for transitional (Niedzica and Czertezik) successions and strictly basinal parts of the basin (Branisko and Pieniny successions). Similar compositions of facies are well known in several European Alpine regions (e.g. Betic Cordillera, Southern Alps, Apennine, Karavanke, and Ionian Zone). These regions, together with PKB basins formed the so-called Alpine Tethys (Golonka, 2004). Very intensive Neo-Cimmerian tectonic movements (latest Jurassic-earliest Cretaceous times), which affected the Czorsztyn Ridge are documented by facies diversification, sedimentary-stratigraphic hiatuses, sedimentary breccias, neptunian dykes and/or fauna redeposition. This tectonic activity was caused by formation and

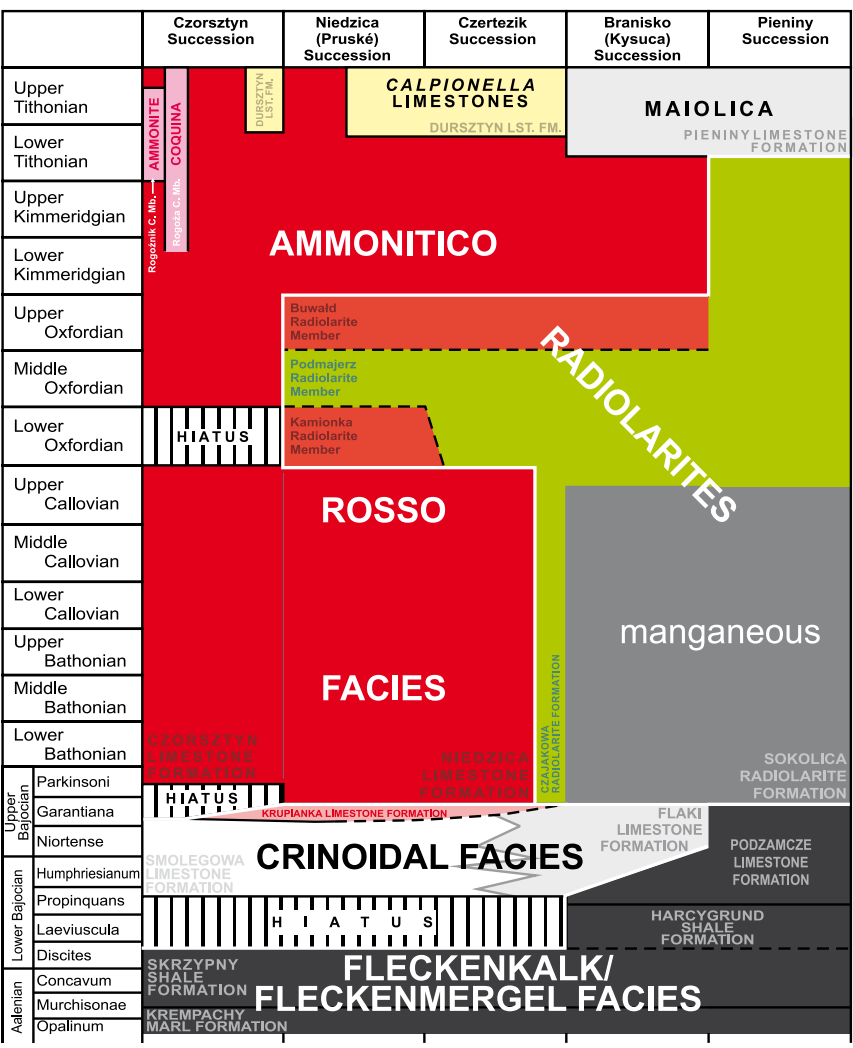

Fig. 7. Stratigraphical correlation between Jurassic lithofacies (lithostratigraphic units) of the Pieniny Klippen Belt successions (after Wierzbowski et al., 2004; supplemented by Krobicki \& Wierzbowski, 2004) • Korelacja stratygraficzna jurajskich litofacji (jednostek litostratygraficznych) sukcesji pienińskiego pasa skałkowego (wg Wierzbowski et al., 2004; uzupełnione przez Krobicki \& Wierzbowski, 2004)

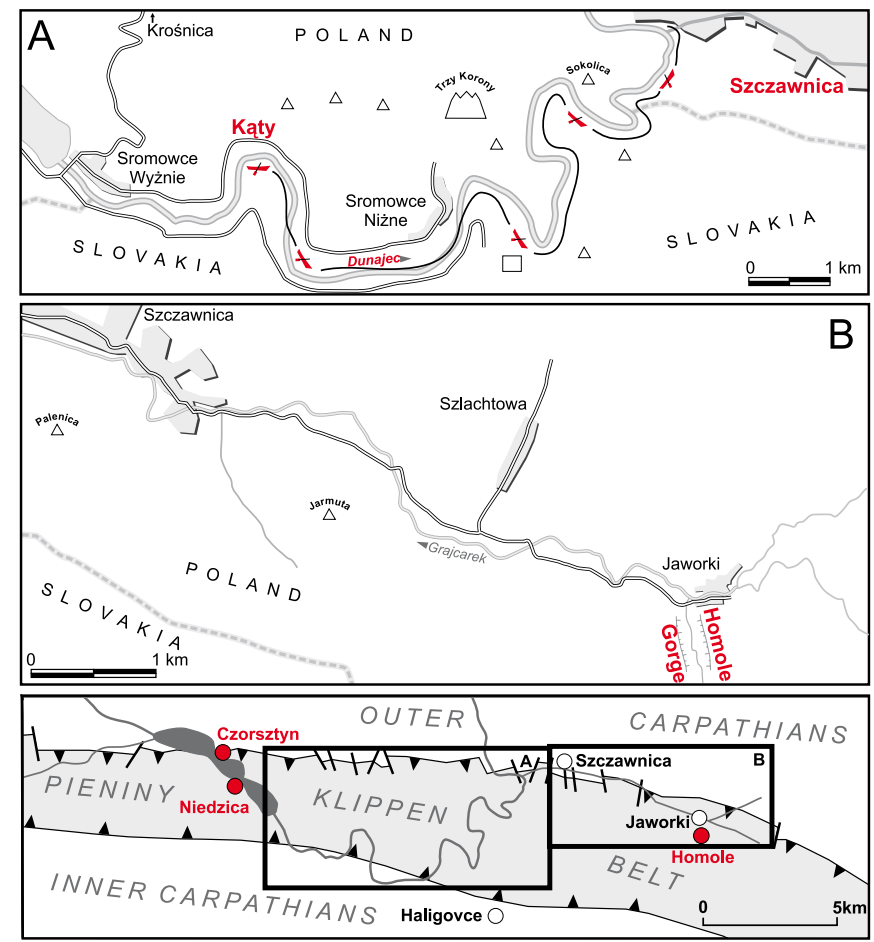

Fig. 8. Polish part of the Pieniny Klippen Belt and location of the Dunajec River Gorge (A) and Homole Gorge (B) • Polska część pienińskiego pasa skałkowego z lokalizacją przełomu Dunajca (A) i Wąwozu Homole (B) 


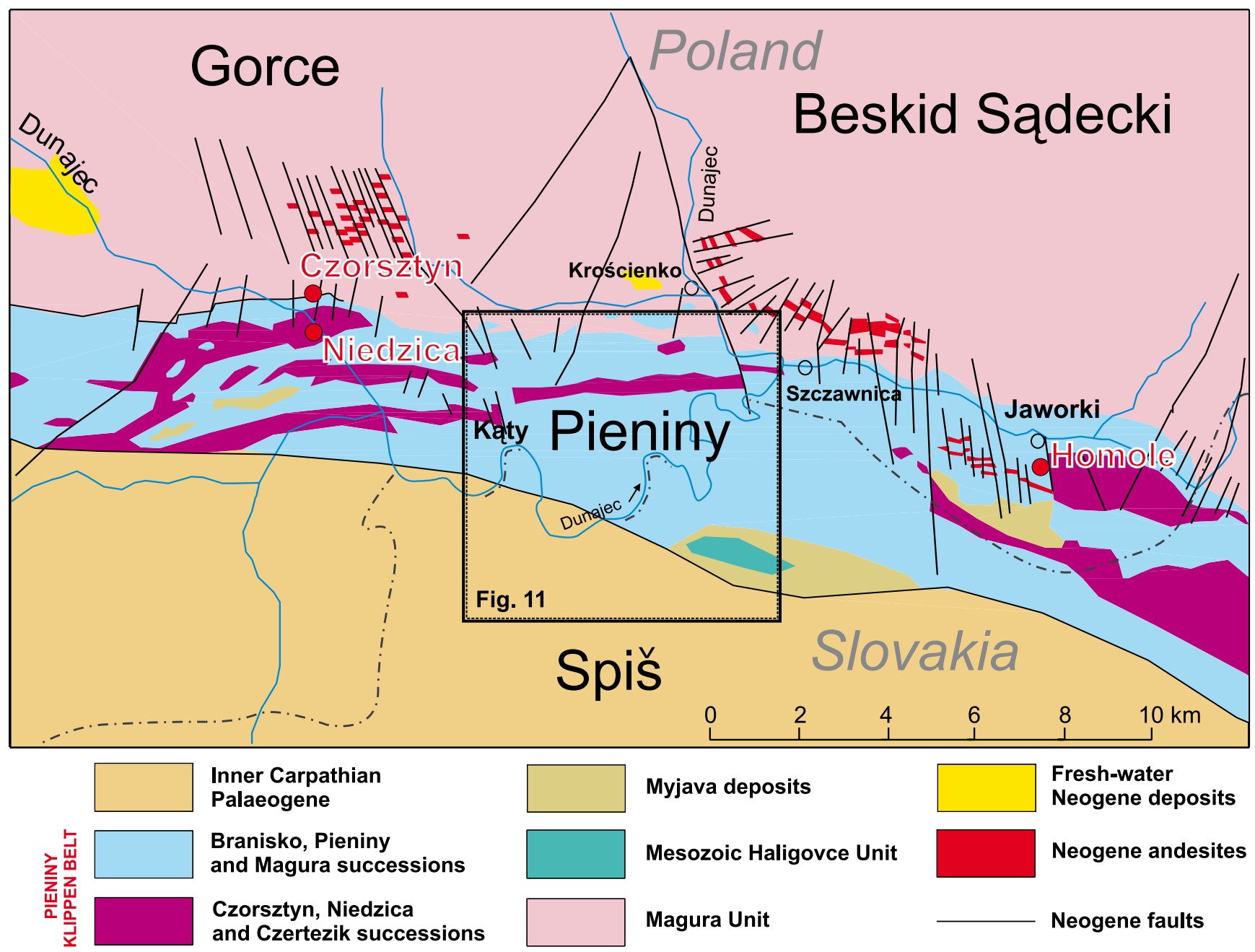

Fig. 9. Geological sketch of the Pieniny Klippen Belt (Polish sector) and surrounding regions (after Birkenmajer, 1979; simplified) with location of Dunajec River Gorge • Szkic geologiczny polskiej części pienińskiego pasa skałkowego i obszarów otaczających (wg Birkenmajer, 1979; uproszczono) z lokalizacją przełomu Dunajca
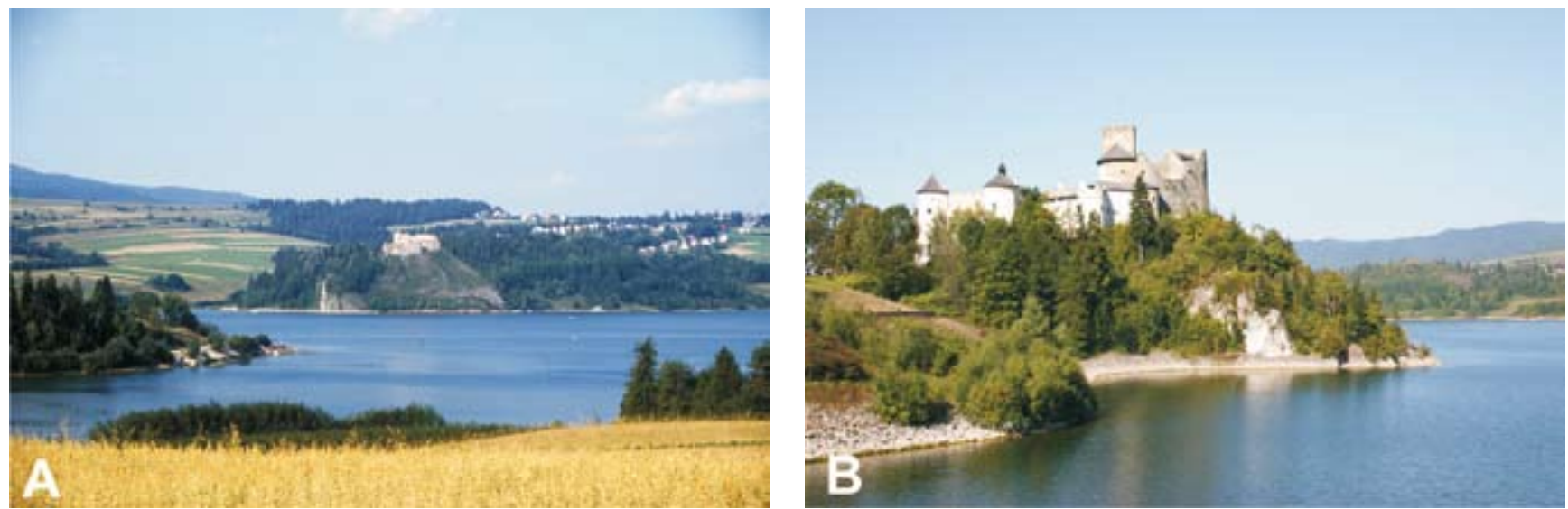

Fig. 10. General view to medieval castles over the artificial Czorsztyn Lake - Czorsztyn Castle (A) and Niedzica Castle (B); location - see Figs 8, 9 - Ogólny widok na średniowieczne zamki nad sztucznym jeziorem czorsztyńskim - zamek w Czorsztynie (A) i zamek w Niedzicy (B); położenie - patrz Fig. 8, 9

Fig. 11. Aerial view of the central Pieniny Mts and Dunajec River Gorge with points of photos: A - Upper Cretaceous red marls of the Scaglia Rossa-type facies (Macelowa Mt); B-E - views to Trzy Korony Mt, Mnichy Mt and Sokolica Mt built by uppermost Jurassic-lowermost Cretaceous Maiolica-type well-bedded limestones, usually strongly tectonic folded (E; hammer for scale), with cherts (see - detail) over Dunajec River Gorge • Zdjęcie lotnicze centralnej części Pienin z przełomem Dunajca z zaznaczeniem miejsc zdjęć: A - czerwone margle górnokredowe facji Scaglia Rossa (Macelowa Góra); B-E - widoki na Trzy Korony, Mnichy i Sokolicę zbudowane z dobrze uławiconych wapieni najwyższej jury-najniższej kredy, zazwyczaj silnie zaburzone tektonicznie (E; młotek jako skala), z rogowcami (patrz - zbliżenie) facji Maiolica, ponad przełomem Dunajca 


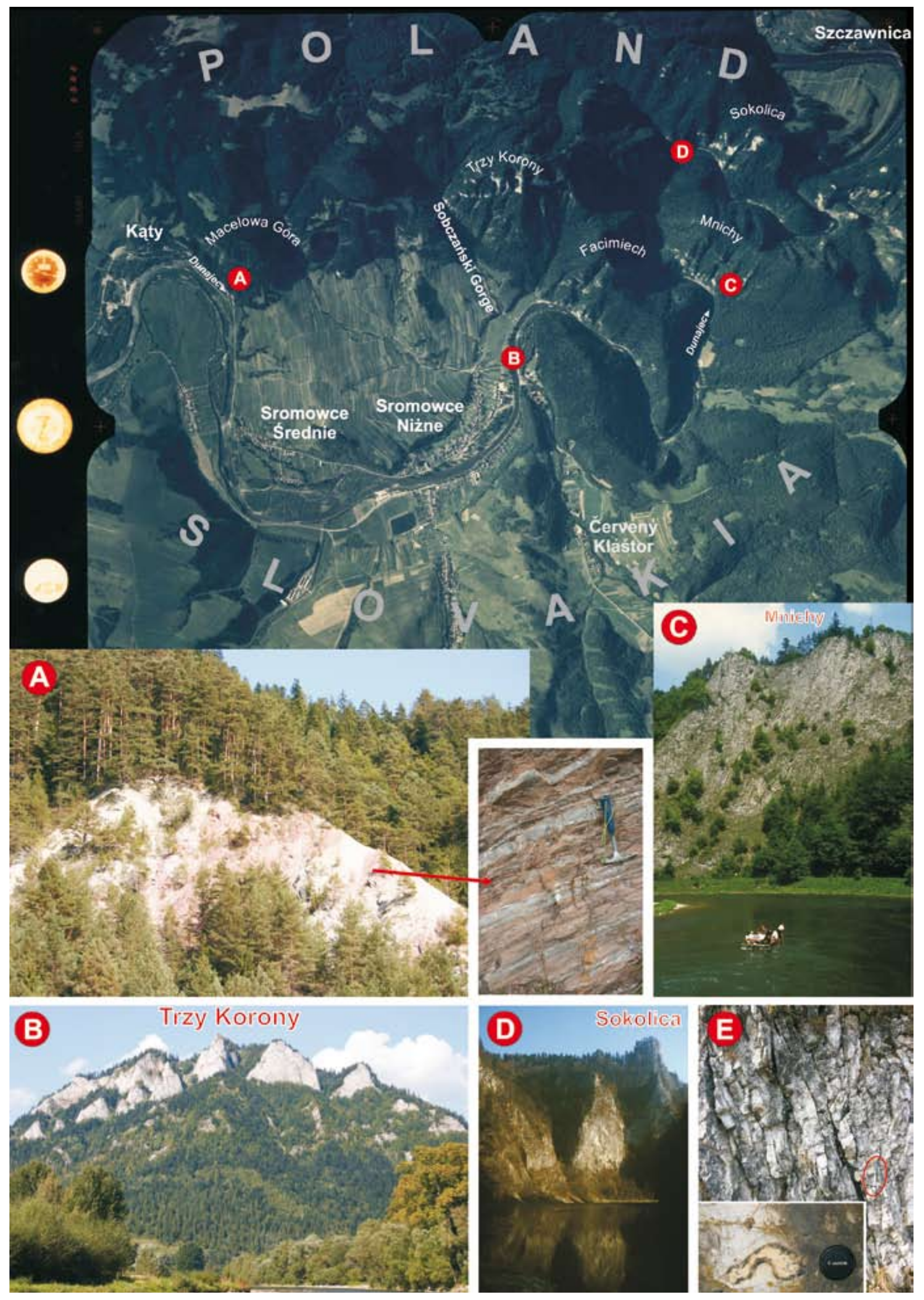



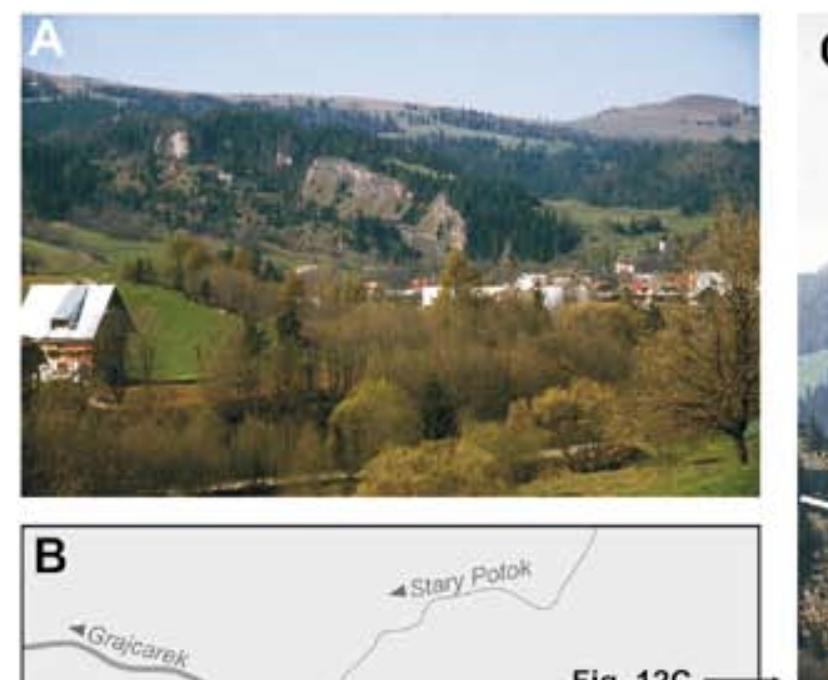

C

Wysokie Skalki
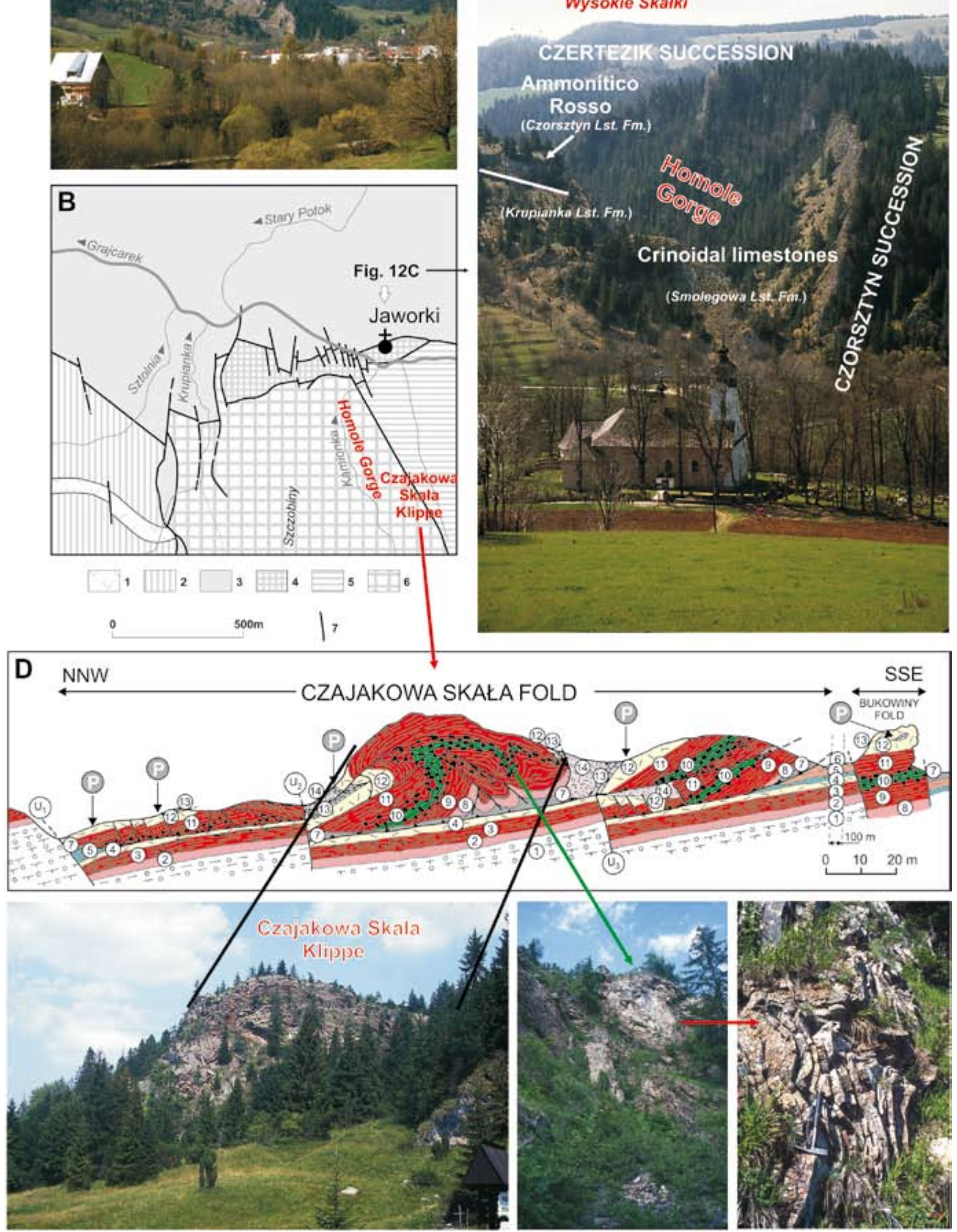


\section{Homole Gorge}

$[\mathrm{m}]$

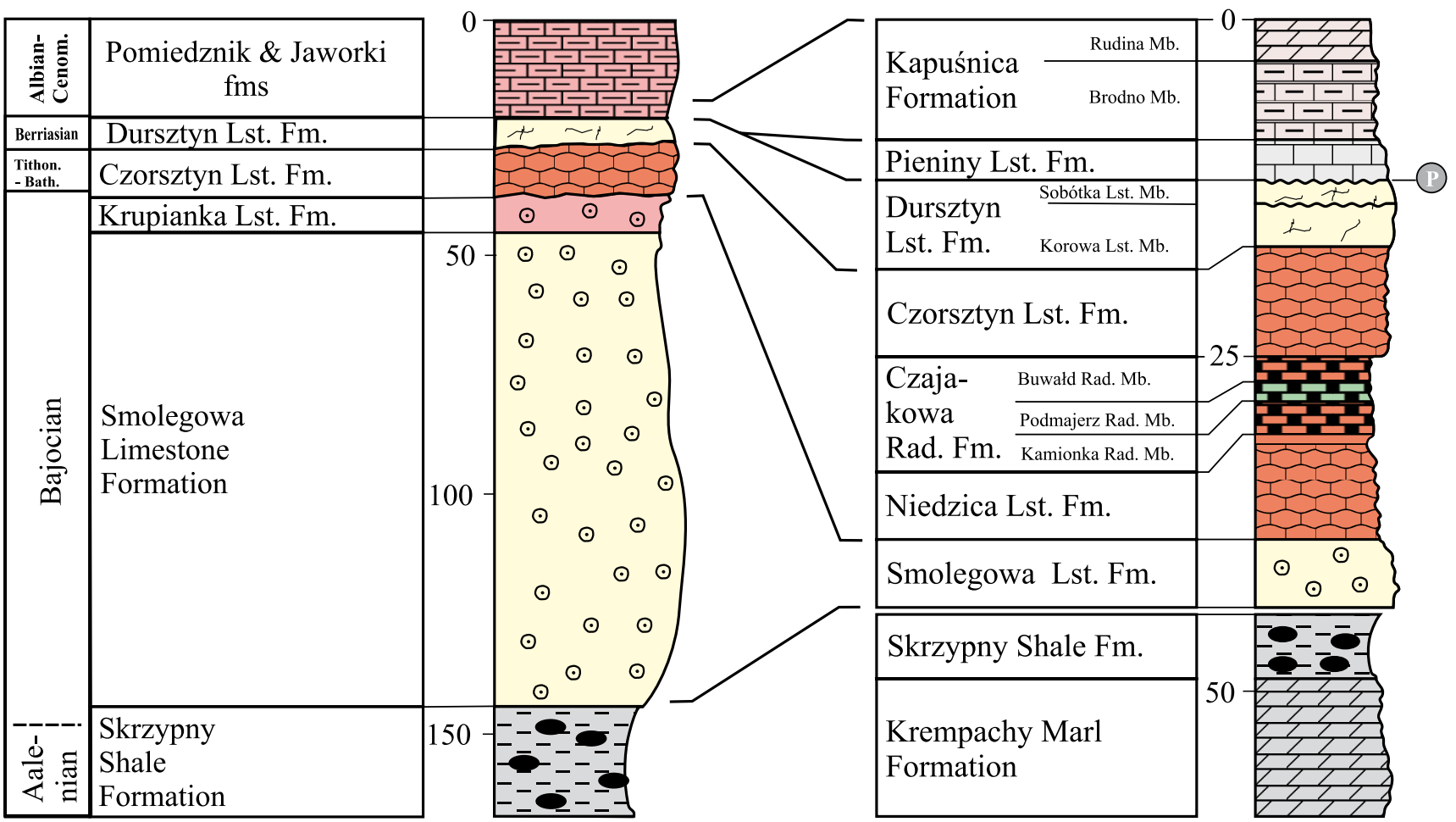

Fig. 13. Lithostratigraphical columns of the Czorsztyn Succession of the Homole Gorge (left) and Niedzica Succession of the Czajakowa Skała klippe (right) (after Birkenmajer, 1977; modified). Explanations of symbols - see the text • Profile litostratygraficzne sukcesji czorsztyńskiej wąwozu Homole (po lewej) i sukcesji niedzickiej Czajakowej Skały (po prawej) (wg Birkenmajer, 1977; zmodyfikowane). Objaśnienia szrafur - patrz tekst

Fig. 12. General panoramic view (A) and geological sketch (B) of vicinity of Jaworki village with more detail view of entrance to Homole Gorge (C) and Czajakowa Skała Klippe and Bukowiny Fold (D) (geology after Birkenmajer, 1970; modified by Jurewicz, 1994). Explanations: B: tectonic sketch of the Homole block, northern part (after Birkenmajer, 1970, 1983); 1 - andesite intrusion (Middle Miocene: Sarmatian); 2 - autochthonous Magura-type Palaeogene; 3 - Grajcarek Unit (Magura Succession); 4 - Czorsztyn Unit (Czorsztyn Succession); 5 - Skalski Stream depression (Niedzica Nappe - Niedzica Succession); 6 - Homole block (Czorsztyn Unit with overthrust Niedzica and Branisko nappes); 7 - strike-slip faults; D: Czorsztyn Succession: 1 - Smolegowa Limestone Fm. (white crinoidal limestones); 2 - Krupianka Limestone Fm. (red crinoidal limestones); 3 - Czorsztyn Limestone Fm. (red nodular Ammonitico Rosso-type limestones); 4 - Dursztyn Limestone Fm. (pink and white Callpionella limestones); 5 - Pomiedznik Fm. (marly limestones); 6-Jaworki Fm. (variegated marls); Niedzica Succession: 7 - Krempachy Marl and Skrzypny Shale formations (--type grey and black spotty marls/shales sometime with spherosiderite concretions - latter formation); 8 - Smolegowa Limestone Fm. (green-red crinoidal limestones); 9 - Niedzica Limestone Fm. (red nodular Ammonitico Rosso-type limestones); 10 - Czajakowa Radiolarite Fm. (red and green radiolarites); 11 - Czorsztyn Limestone Fm. (red nodular Ammonitico Rosso-type limestones); 12 - Dursztyn Limestone Fm. (red and white Callpionella limestones); 13 - Pieniny Limestone Fm. (white and grey cherty Maiolica-type limestones); 14 - Kapuśnica Fm. (greenish spotty limestones). P - Location of phosphate deposits on the uppermost surface of the Sobótka Limestone Member of the Dursztyn Limestone Fm. (formal units after Birkenmajer, 1977) • Ogólna panorama (A) i szkic geologiczny (B) okolic wsi Jaworki z bardziej szczegółowym widokiem na wejście do wąwozu Homole (C) oraz na Czajakową Skałę i fałd z Bukowin (D) (geologia wg Birkenmajer, 1970; zmodyfikowane przez Jurewicz, 1994). Objaśnienia: B: szkic tektoniczny bloku Homoli, część północna (wg Birkenmajer, 1970, 1983); 1 -intruzje andezytowe (środkowy miocen: sarmat); 2 - paleogen autochtoniczny typu magurskiego; 3 -jednostka Grajcarka (sukcesja magurska); 4 -jednostka czorsztyńska (sukcesja czorsztyńska); 5 - depresja Skalskiego potoku (płaszczowina niedzicka - sukcesja niedzicka); 6 - blok Homoli (jednostka czorsztyńska z nasunięciem płaszczowiny niedzickiej i braniskiej); 7 - uskoki przesuwcze; D: sukcesja czorsztyńska: 1 - formacja wapienia ze Smolegowej (białe wapienie krynoidowe); 2 - formacja wapienia z Krupniaki (czerwone wapienie krynoidowe); 3 - formacja wapienia czorsztyńskiego (czerwone wapienie bulaste typu Ammonitico Rosso); 4 - formacja wapieni dursztyńskich (różowe i białe wapienie kalpionellowe); 5 - formacja z Pomiedznika (wapienie margliste); 6 - formacja z Jaworek (margle pstre); sukcesja niedzicka: 7 - formacje margli z Krempachów i łupków ze Skrzypnego (szare i czarne plamiste margle/łupki typu Fleckenmergel niekiedy z konkrecjami sferosyderytów - druga z formacji); 8 - formacja wapienia ze Smolegowej (zielono-czerwone wapienie krynoidowe); 9 - formacja wapienia niedzickiego (czerwone wapienie bulaste typu Ammonitico Rosso); 10 - formacja radiolarytów z Czajakowej (czerwone i zielone radiolaryty); 11 - formacja wapienia czorsztyńskiego (czerwone wapienie bulaste typu Ammonitico Rosso); 12 - formacja wapieni dursztyńskich (różowe i białe wapienie kalpionellowe); 13 - formacja wapienia pienińskiego (białe i szare wapienie rogowcowe typu Maiolica); 14 - formacja z Kapuśnicy (zielonkawe wapienie plamiste). P - lokalizacja utworów sfosfatyzowanych na powierzchni ogniwa wapieni z Sobótki formacji wapieni dursztyńskich (jednostki formalne wg Birkenmajer, 1977) 

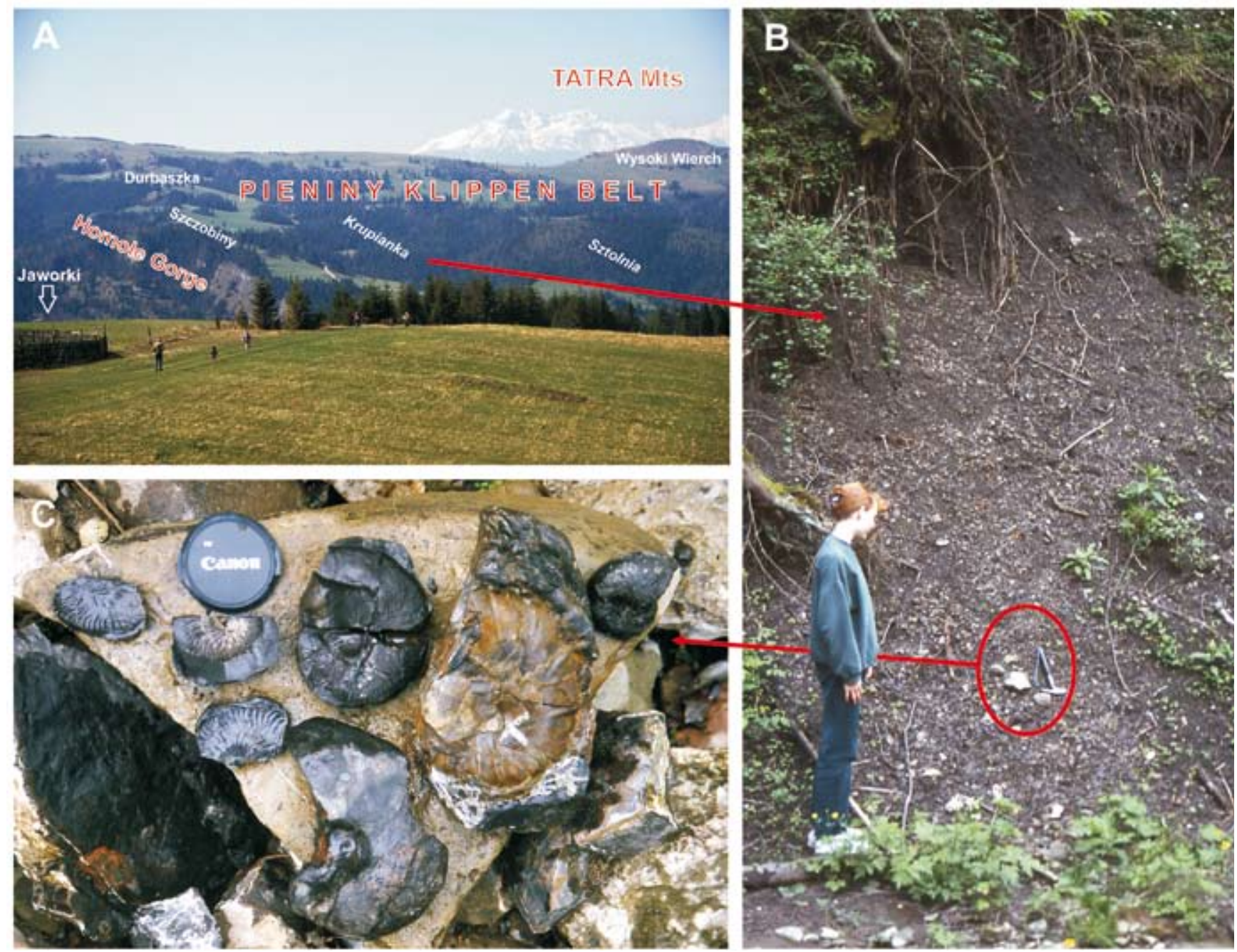

Fig. 14. General, panoramic view on Tatra Mts and Pieniny Klippen Belt regions from vicinity of Jaworki village (A) and location in Krupianka stream of the Middle Jurassic (Aalenian-lowermost Bajocian) black shales with spherosiderites (Skrzypny Shale Formation) (B) sometime full of ammonites (C) • Ogólny, panoramiczny widok na Tatry i pieniński pas skałkowy z okolic wsi Jaworki (A) i lokalizacja w potoku Krupianka środkowojurajskich (aalen-najniższy bajos) czarnych łupków sferosyderytowych formacji łupków ze Skrzypnego (B) czasami obfitych w amonity (C)

destruction of submarine tectonic horsts in the Carpathian basins (Birkenmajer, 1958, 1975, 1986; Michalík \& Reháková, 1995; Krobicki, 1996; Krobicki \& Słomka, 1999; Golonka et al., 2003; Krobicki et al., 2006). During latest Jurassic-earliest Cretaceous times (Tithonian-Berriasian) cherty limestones of Maiolica-type (=Biancone) facies were deposited within deeper successions. It is one of the famous, widespread Tethyan facies well known both from the Alpine and the Apennine regions of the Alpine Tethys (Pszczółkowski, 1987; Wieczorek, 1988). These white-gray, micritic well-bedded calpionellids-bearing limestones build now the highest part of the Pieniny Mts (e.g., Trzy Korony Mt, Sokolica Mt etc). The Late Cretaceous history of the PKB basin is connected with unification of sedimentary regimes within ridge and slope successions (Albian-Coniacian), and deposition of multicoloured green/variegated/red marls full of foraminiferids (the youngest are Scaglia Rossa-type pelagic red marls - Birkenmajer, 1986; Bąk, 2000). The syn-orogenic flysch deposits developed in the basinal parts during the last episode of the history of the PKB basin. Then, the Czorsztyn Ridge collided with the Inner Carpathian terranes around the Cre-
taceous/Palaeogene boundary (Birkenmajer, 1986). The post-orogenic subvolcanic activities took place in this region mainly during Miocene times - (Birkenmajer, 2003 with literature cited therein). Now, the PKB is strictly tectonic zone reflecting its Palaeogene-Neogene evolution when (sub) vertical faults and shear zones developed and a strong reduction of space of the original sedimentary basins took place.

\section{Selected most famous geological objects in the Pieniny Klippen Belt and their geotouristic values}

\section{Rafting trough Dunajec River Gorge}

One of the major geotouristic attraction of the Pieniny Klippen Belt region is the rafting through the Dunajec River Gorge (Golonka \& Krobicki, 2007, see also Alexandrowicz $\&$ Alexandrowicz, 2004). The rafting trip on the Dunajec River, which starts at Sromowce Kąty harbour (Figs 8, 9), takes geotourist through the Dunajec Gorge to Szczawnica. The Dunajec offers magnificent view of the cliffs sculptured 
in the Pieniny Mountains by the tectonic activity and river's erosion. It offers also the close view of the outcrops of Jurassic and Cretaceous rocks of the Pieniny Succession and complex tectonics of the PKB.

The Katy's harbor has good connection with main touristic points in the Pieniny Mts and is easily accessible both from Zakopane (from south) and from Kraków (from north). Katy are located very close to famous medieval castles (Czorsztyn Castle - Fig. 10A and Niedzica Castle - Fig. 10B), which occupied good accessible and visible places just above artificial Czorsztyn Lake.

The Macelowa Mt (Fig. 11) is the first viewpoint along our boat trip. The Oxfordian radiolarites and latest JurassicEarly Cretaceous gray cherty limestones of the Maiolica facies (Pieniny Limestone Formation) of the Pieniny Succession, occupy topmost and middle part of this mountain in completely overturned position. Therefore, the youngest part of this succession occurs in lowest (topographically) position and is represented by the Late Cretaceous Globotruncanabearing marls of the Scaglia Rossa-type deposits (Fig. 11A) (Birkenmajer, 1979; Bąk, 2000). In close view we can see red marls and marly limestones with greyish intercalations of calcareous sandstones and siltstones of turbiditic origin connected with distal parts of submarine fans, typical flysch and flyschoidal sedimentation (comp. Mutti \& Ricci Lucchi, 1975; Słomka, 1986; Stow, 1986; Mutti \& Normark, 1987; Ghibaudo, 1992; Reading \& Richards, 1994; Lowe, 1997; Shanmugam, 2000). The red Globotruncana marls of the Scaglia Rossa-type facies (in local nomenclature - Macelowa Marl Member of the Jaworki Formation; Birkenmajer, 1977), which we can see now, is the youngest part of this unit. The Jaworki Formation is composed (stratigraphically) by green-variegated-red globotruncanid marls with perfect studied biostratigraphy $(\mathrm{Bak}, 2000)$. Such type of facies is wide known both from Alpine and Apennine geology. The primary seaways between several parts of the Tethyan Ocean, especially the above mentioned Alpine Tethys (Golonka, 2004), which existed during the Late Cretaceous times are very well documented by these facies occurrences. Later, Dunajec River crosses through several vertical strike-slip faults, which separate the Pieniny Klippen Belt from the Central Carpathians Palaeogene Flysch region (precisely - Oligocene in age). At Sromowce Niżne village (Figs 8, 11) the Dunajec River enters again Pieniny Klippen Belt.

The most famous and beautiful peak of the Pieniny Mts - Trzy Korony Mt (Three Crowns) (982 m a.s.1.) (Fig. 11B) is good visible at the beginning of the Dunajec River Gorge (Birkenmajer et al., 2001). In local, folk nomenclature, the Trzy Korony peak is known as (from left to right): Kaśka (Kate), Zośka (Sophie) and Kudłata Maryśka (Hairy Mary). The very steep walls of this peak are formed by strongly folded thin-bedded, grey, cherty limestones of the Maiolica (=Biancone) facies of the Pieniny Limestone Formation (Kimmeridgian-Albian) of the Pieniny Succession.

The origin of the Dunajec River Gorge is connected with young, mainly Neogene history, related to the neotectonic movements. This river have had the mature stage in the latest Miocene-Pliocene time, and manifested by meandering shape. Then, during episode of the uplifting of the Pieniny Mts, such shape of the river have been conserved, when more competent Late Cretaceous marls and marly limestones, softer than Jurassic/Early Cetaceous cherty limestones, which occurred between several tectonic slices, have been easily eroded by the Dunajec River water, during the fault-related uplift. Origin of strongly faulted, usually thin-bedded Maiolica-type cherty limestones is connected with this tectonic activity of Alpine orogeny (Fig. 11E). Some of the faults were still active during the Quaternary and were connected with rare earthquakes (Baumgart-Kotarba, 1996, 2001; Zuchiewicz et al., 2002 and references therein). Recently vertical movements reached up to $+0.5 \mathrm{~mm}$ per year, according to very detail geodetic measurements (Vanko, 1988; Vass, 1998). Detail description of origin and age of the Dunajec River Gorge, with the review of structural and geomorphological features of the Pieniny Mts and formation of magnificent cliffs of the Gorge, was published by Birkenmajer (2006) (see also - Zuchiewicz, 1982).

The next interesting point on the right bank of the Dunajec River is the medieval Czerwony Klasztor (Red Monastery) constructed in 1330, where one of the Camelot's pharmacist (Brother Cyprian - Franciszek Ignacy Jeszke) collected a huge quantity of plants (282 species), both from the Pieniny and Tatra mountains.

The Pieniny Limestone Formation builds steep cliffs along the Dunajec River Gorge, described in more detail by Golonka \& Krobicki (2007). One of the most spectacular views along rafting trip is Mnichy (Seven Monks) (Fig. 11C) and Sokolica Mt (Falcon's Mt) (Fig. 11D). The name of this mountain is derived from numerous falcons, which used to nest here.

The Sokolica is frequently visited by hikers because of magnificent view of the Tatra Mts and the ancient, 500 yearsold pine forest (Tłuczek, 2004). Close to the Szczawnica town, the Dunajec River Gorge ended, just after the last cliff built by thin-bedded cherty limestones. This town is popular spa, famous for its mineral springs, which have been known since the medieval time, but first written remarks came from XVI century.

After rafting on Dunajec River we will go eastward to Jaworki village. The Grajcarek stream valley runs parallel with the Pieniny Klippen Belt, where Jurassic and Lower Cretaceous rocks of the so-called tectonic Grajcarek Unit are exposed (with full development of the Magura (Hulina) Succession). This succession was deposited within the northwestern part of the Carpathian Tethys, separated palaeogeographically by the Czorsztyn Ridge from the other basinal succession (Birkenmajer, 1986; Golonka, 2004; Golonka \& Krobicki, 2004). On the northern side this unit is in tectonic contact with the flysch rocks of the Krynica Unit of the Magura Nappe. Several Miocene andesite intrusions cut both tectonic units (Malinów abandoned quarry, Jarmuta and Krupianka hills).

\section{Homole Gorge near Jaworki village}

The famous deep Homole Gorge is cutting through the rocks of the so-called Homole tectonic block south of the Jaworki village (Figs 8, 9, 12-14). The origin this block is speculative and a subject of scientific debate. There is a variety of opinions, from the autochthonous position within the Czorsztyn ridge (e.g. Birkenmajer, 1986) through the nappe 
thrust over the other tectonic units (e.g. Książkiewicz, 1977; Golonka \& Raczkowski, 1984; Jurewicz, 1997, 2005) to the olistoliths (Cieszkowski \& Golonka, 2005, 2006; Cieszkowski et al., 2008). In the Homole Gorge up to near $100 \mathrm{~m}$ thick section of white crinoidal limestones of the Smolegowa Limestone Formation of the Czorsztyn Succession is exposed (Birkenmajer, 1963, 1977). These limestones are overlain by red crinoidal limestones (of the Krupianka Limestone Formation) and Ammonitico Rosso-type nodular limestones of the Czorsztyn Limestone Formation, which reach maximum 20 $\mathrm{m}$ in thickness. Both Smolegowa and Krupianka formations are Bajocian (Middle Jurassic) in age whereas condensed nodular limestones of the Ammonitico Rosso facies (Czorsztyn Limestone Formation) represent Middle Jurassic to Early Cretaceous. The decrease of sedimentation rate in pelagic sedimentation regime happened during late Middle-Late Jurassic times. This phenomenon is recorded by the deepening-upward sequence of deposits. The famous Pieniny Klippen Belt tectonic fold and thrust structures can be observed in the Czajakowa Skała Klippe in the upper part of the Homole Gorge (Birkenmajer, 1970, 1979) (Fig. 12D). The Niedzica Nappe is there thrust here over the thick Czorsztyn Unit. Several beds representing the red nodular limestones of the Ammonitico Rosso-type of the Niedzica Limestone Formation and Czorsztyn Limestone Formation as well as intercalated radiolarites of the Czajakowa Radiolarite Formation are strongly tectonically disturbed, forming the overturned fold (Birkenmajer, 1970; Jurewicz, 1994) (Fig. 12D). The type locality of the Czajakowa Radiolarite Formation occurs within this klippe (Fig. 13). The Czajakowa Skała Klippe also shows a complete sequence of the Jurassic deposits of the Niedzica Succession (Birkenmajer, 1977; Wierzbowski et al., 1999). The oldest black and grey marly shales with spherosiderite concretions of the Skrzypny Shale Formation (Birkenmajer, 1977; Tyszka, 1994) are exposed here. These deposits are overlain by yellowish-greyish-red and dark cherry-greenish crinoidal limestones. The contact between black shales and crinoidal limestones is sharp and irregular. The ammonite fauna was found in the lowermost part of the crinoidal limestones of the Smolegowa Limestone Formation. These very precise biostratigraphical data suggest a hiatus between black shales and crinoidal limestones, spanning the Laeviuscula and a part of Propinquans ammonite zones of the Lower Bajocian (Middle Jurassic) (Krobicki \& Wierzbowski, 2004; Krobicki, 2006). The small outcrops of these black shales occur below Czajakowa Skała Klippe within local landslide. The best outcrops of these rocks within the Pieniny Klippen Belt in Poland occur in the Krupianka stream, which run the Homole Gorge, westward. Their thickness reach 4-5 metres. The shales contain a lot of spherosiderites and sometimes perfectly preserved ammonites (Fig. 14). The ammonite fauna indicates latest of Aalenian and/or earliest of Bajocian (Middle Jurassic) age of black shales, representing oxygendepleted facies of the Fleckenmergel-type. $\square$

This research has been financially supported by AGH grant (11.11.140.447)

\section{Streszczenie}

\section{Geologiczna historia pienińskiego pasa skatkowego a środkowojurajskie czarne łupki jako jedne $z$ najstarszych utworów regionu - stratygraficzna pozycja i paleośrodowiskowe znaczenie}

\section{Michał Krobicki \& Jan Golonka}

Karpaty Zewnętrzne (fliszowe) i pieniński pas skałkowy tworzą najbardziej północną część polskich Karpat. Te pierwsze są zbudowane przez fliszowe utwory jurajsko-wczesnomioceńskie (Ślączka, 1996; Oszczypko, 2004, 2006a, b; Oszczypko et al., 2005, 2006). Utwory te były oderwane od swojego podłoża i fałdowane oraz nasuwane od południa w miocenie (orogeneza alpejska) formując płaszczowiny (Ślączka, 1996). Wszystkie płaszczowiny Karpat Zewnętrznych są nasunięte na platformę wschodnioeuropejską przykrytą utworami miocenu zapadliska przedkarpackiego (Fig. 1, 2). Płaszczowiny są elementem allochtonicznym, a utwory je budujące powstawały w karpackich basenach sedymentacyjnych, daleko na południe od ich dzisiejszego miejsca występowania. Pieniński pas skałkowy (pps) natomiast, znajduje się na granicy Zewnętrznych Karpat Fliszowych i Karpat Wewnętrznych, stanowiąc bardzo silnie stektonizowaną strefę, która dzisiaj ma około 600 km długości i 1-20 km szerokości, biegnąc od okolic Wiednia na zachodzie aż do Rumunii na wschodzie. (Fig. 1). Zarówno północna jak i południowa granica pps są dzisiaj granicami tektonicznymi, mając prawie pionowy przebieg (Fig. 3), wzdłuż których następowało tektoniczne skracanie oryginalnego basenu sedymentacyjnego (Birkenmajer, 1986; Golonka \& Krobicki, 2006; Krobicki \& Golonka, 2006). W swoim regionalnym charakterze pps jest generalnie strefą melanżu tektonicznego, gdzie poszczególne jednostki tektoniczne są trudne do rozróżnienia.

Palinspastyczna rekonstrukcja basenu pps wskazuje na występowanie podmorskiego grzbietu podczas jego jurajskokredowej historii. Jest to tzw. grzbiet czorsztyński, który stanowił wydłużoną strefę, rozdzielającą pierwotnie basen magurski (Karpat Zewnętrznych) od basenu pienińskiego w obrębie najbardziej północnej części oceanu Tetydy (Fig. 4-6) (por. Golonka, 2007a, b z literaturą tam cytowaną). Geograficzna orientacja tego grzbietu, z SW na NE, jest interpretowana na podstawie badań paleomagnetycznych, analizy facjalnej osadów mezozoicznych jak i warunków paleoklimatycznych (patrz dyskusja - Golonka \& Krobicki, 2001; oraz Aubrecht \& Túnyi, 2001; Lewandowski et al., 2005; Grabowski et al., 2008). Baseny sedymentacyjne rozdzielone przez grzbiet czorsztyński były zdominowane przez pelagiczny typ sedymentacji. Najgłębsze części basenu pps są dobrze udokumentowane przez jurajsko-wczesnokredowe utwory głębokowodne (radiolaryty i wapienie rogowcowe typu $\mathrm{Ma}$ iolica) (Birkenmajer, 1979, 1986; Golonka \& Sikora, 1981; Golonka \& Krobicki, 2004; Krobicki et al., 2006) tzw. sukcesji braniskiej i pienińskiej. Nieco płytsze, przejściowe 
sukcesje (czertezicka i niedzicka) okupowały miejsce odpowiadające skłonowi kontynentalnemu pomiędzy głębszymi partiami basenu a częścią najpłytszą, reprezentowaną przez sukcesję czorsztyńską, która zajmowała pierwotnie SE skłon grzbietu czorsztyńskiego (Birkenmajer, 1986; Krobicki \& Golonka, 2006).

Najwcześniejsze stadium historii basenu pienińskiego jest enigmatyczne i udokumentowane jedynie egzotykami z fliszowych utworów kredy i paleogenu. Egzotyki te sugerują istnienie hipotetycznej ,zatoki” oceanu Vardar-Transylwania, który oddzielał blok Cisy (rejon Bihor-Apuseni) od platform mezyjskiej i wschodnioeuropejskiej (Săndulescu, 1988; Golonka \& Krobicki, 2004). Najstarsze utwory jury pps (hetangsynemur) znane są tylko na Słowacji i Ukrainie i reprezentowane są przez zróżnicowane, szaro-czarne utwory klastyczne facji gresteńskiej z nielicznymi wkładkami czarnych wapieni (Schlögl et al., 2004 z literaturą). Natomiast młodsze (toark-dolny bajos) są wapienie i margle plamiste facji Fleckenkalk/Fleckenmergel i czarne łupki sferosyderytowe z małżami Bositra („Posidonia”) (w lokalnej terminologii formacja łupków ze Skrzypnego; Birkenmajer, 1977), powstałe w okresowo niedotlenionych środowiskach sedymentacji oceanu Tetydy (Birkenmajer, 1986; Tyszka, 1994, 2001). We wczesnym bajosie (jura środkowa) grzbiet czorsztyński ukształtował się jako wyraźny grzbiet śródoceaniczny, z czym związana była równocześnie bardzo gwałtowna zmiana sedymentacji/paleośrodowiska, kiedy dobrze dotlenione, różnokolorowe (białe, żółtawe, różowe, szare, czerwone) wapienie krynoidowe zastąpiły szare i czarne niedotlenione utwory wczesnej jury i początków jury środkowej (Krobicki \& Wierzbowski, 2004). Te wapienie krynoidowe osadzały się w najpłytszych i przejściowych sukcesjach osadowych (czorsztyńska, niedzicka i czertezicka). Bajoskie wynurzenie grzbietu czorsztyńskiego pomiędzy basenem pienińskim a magurskim było związane $\mathrm{z}$ postryftową fazą ewolucji basenu pienińskiego i najprawdopodobniej odpowiada pierwszym epizodom ruchów fazy mezokimeryjskiej orogenezy alpejskiej (Golonka et al., 2003; Krobicki, 2006). Nieco później (od najpóźniejszego bajosu) osadziły się czerwone, pelagiczne wapienie bulaste facji Ammonitico Rosso. W tym samym czasie w najgłębszych partiach basenu pps tworzyły się po raz pierwszy radiolaryty (Birkenmajer, 1986; Mišík, 1999). Późnojurajska (oksford-kimeryd) historia basenu pienińskiego ukazuje jego najsilniejsze zróżnicowanie facjalne z sedymentacją mieszanych utworów krzemionkowo-wapiennych. Te pierwsze osadzały się w relatywnie płytszych środowiskach sedymentacji (np. sukcesja czorsztyńska), a radiolaryty powstawały w sukcesjach przejściowych i basenowych (Birkenmajer, 1977, 1986; Mišík, 1999). Na przełomie jury i kredy efekt działania neokimeryjskich ruchów tektonicznych, doprowadził do silnego zróżnicowania facjalnego. Formowanie się i destrukcja podmorskich zrębów tektonicznych jest utożsamiana $\mathrm{z}$ dużą aktywnością tektoniczną $\mathrm{w}$ basenach karpackich w tym czasie (Birkenmajer, 1958, 1975, 1986; Michalík \& Reháková, 1995; Krobicki, 1996; Aubrecht et al., 1997; Krobicki \& Słomka, 1999; Plašienka, 2002; Golonka et al., 2003; Krobicki et al., 2006). Równocześnie w głębszych partiach basenu pienińskiego (głównie sukcesja braniska i pienińska) trwała sedymentacja mikrytowych wa- pieni rogowcowych facji Maiolica (=Biancone). Jest to jedna z najszerzej rozprzestrzenionych litofacji w całej Tetydzie (Pszczółkowski, 1987; Wieczorek, 1988). W polskiej części Pienin te białe, cienkouławicone wapienie budują najwyższe szczyty tych gór (np. Trzy Korony, Sokolica etc.). Pelagiczne margle otwornicowe, początkowo zdominowane przez hedbergelle, dokumentują $z$ kolei albski (najmłodsze piętro wczesnej kredy) etap sedymentacji w basenie (Birkenmajer, 1986). Natomiast późnokredowe utwory pelagiczne, zdominowane są przez czerwone margle globotrunkanowe (najpopularniejszy rodzaj otwornic w tym czasie) facji Scaglia Rossa (Birkenmajer, 1986; Bąk, 2000).

Jedną z największych atrakcji geoturystycznych pienińskiego pasa skałkowego jest spływ Dunajcem, opisana ostatnio szczegółowo przez Golonkę \& Krobickiego (2007) (patrz również Alexandrowicz \& Alexandrowicz, 2004) i z tego powodu tutaj tylko lakonicznie wzmiankowana. Początek spływu ma miejsce na przystani Kąty (Fig. 8, 9) we wsi Sromowce i kończy się w Szczawnicy (ok. 2-2.5 godziny). Dogodne połączenia komunikacyjne tego miejsca umożliwiają łatwe dotarcie tutaj zarówno od północy (Kraków) jak i od południa (Zakopane). Wycieczka ta oferuje nadzwyczajne widoki stromych ścian centralnych Pienin, uformowanych tak zarówno dzięki procesom tektonicznym jak i erozji rzecznej. Przy okazji można odwiedzić niedalekie, średniowieczne zamki w Czorsztynie (Fig. 10A) bądź w Niedzicy (Fig. 10B). Na trasie spływu pierwszym interesującym obiektem geologicznym (geoturystycznym) jest Macelowa Góra (Fig. 11), która w odwróconej pozycji tektonicznej ukazuje ciągły profil utworów najwyższej jury-dolnej kredy sukcesji pienińskiej (od górnojurajsko-dolnokredowych wapieni rogowcowych facji Maiolica na górze aż po górnokredowe margle globotrunkanowe facji Scaglia Rossa na dole). W obrębie tych margli można zaobserwować cienkie (kilka cm) wkładki turbidytowych piaskowców i mułowców, których geneza ściśle nawiązuje do głębokomorskiej sedymentacji typu fliszowego (por. Mutti \& Ricci Lucchi, 1975; Słomka, 1986; Stow, 1986; Mutti \& Normark, 1987; Ghibaudo, 1992; Reading \& Richards, 1994; Lowe, 1997; Shanmugam, 2000). Kolejnymi spektakularnym obiektami na trasie spływu są Trzy Korony (982 m n.p.m.) (Fig. 11B) i Sokolica (Fig. 11D), najwyższe szczyty centralnych Pienin, prawie w całości zbudowane z cienkoławicowych, silnie tektonicznie zdeformowanych wapieni rogowcowych facji Maiolica, również należących do sukcesji pienińskiej. Natomiast, tektoniczno-erozyjna historia Przełomu Dunajca była obiektem zainteresowania już XIX-to wiecznych geologów, lecz nie do końca w szczegółach rozpoznany jest fenomen jego powstania mimo upływu tylu lat od tamtych czasów (zob. Zuchiewicz, 1982; Birkenmajer, 2006). Przełom ten tworzy wiele łusek tektonicznych ponasuwanych na siebie a zbudowanych głównie z twardych, odpornych na erozję wapieni rogowcowych, a przekładających się wielokrotnie (łuski tektoniczne) z mniej odpornymi na wietrzenie i erozję marglami i łupkami, głównie górnej kredy. Bezsprzeczny jest związek budowy geologicznej tego obszaru, a zwłaszcza jego plan strukturalno-tektoniczny, z genezą Przełomu Dunajca, co w świetle najnowszych danych neotektonicznych zyskuje nowe argumenty (Zuchiewicz et al., 2002). W historii badań tego frapującego 
zagadnienia proponowano co najmniej cztery rozwiązania. Najstarszy z nich preferował genezę epigenetyczną, uznając, że Dunajec wcinał się w miękkie utwory przykrywające zwartą pokrywą wapienne skałki podłoża. Drugi pogląd skupiał się na antecedentnej genezie Przełomu Dunajca, sugerując powolne podnoszenie się górotworu pienińskiego i stopniowe wcinanie się meandrującego pierwotnie pra-Dunajca w podłoże. Pomysł trzeci wskazuje na tektoniczne uwarunkowania powstania przełomu (płynie on obecnie po utworach budujących maksymalną depresję strukturalną) i dlatego został nazwany przełomem strukturalnym. Ostatnia z propozycji rozważa możliwość kaptażu systemu rzecznego Białki-Białego Dunajca przez tzw. „Dunajec sądecki”, co miało wywołać efekt erozji wstecznej, a przez to Przełom Pieniński można by uznać za przełom regresyjny. Bez względu na to, która z propozycji jest prawdziwa, przebieg procesu formowania się przełomu miał miejsce pomiędzy późnym miocenem a plejstocenem jak ostatnio to zreasumował Birkenmajer (2006) w nawiązaniu do najnowszych obserwacji tego fenomenu.

Po spływie Dunajcem udajemy się w kierunku wsi Jaworki, na wschód za Szczawnicę, aby zwiedzić słynny Wąwóz Homole (Fig. 8, 9, 12-14). Jest to praktycznie jedyne miejsce w pienińskim pasie skałkowym Polski gdzie wapienna płyta, pochylona nieznacznie pod stosunkowo niewielkim kątem ku północy, jest relatywnie słabo zaburzona tektonicznie. Dlatego w terminologii geologicznej tego obszaru zwykło się używać określenia „tektoniczny blok (płyta) Homoli” (Birkenmajer, 1970, 1979), dla skrótowego zobrazowania jego charakteru strukturalnego. Prawie ze wszystkich stron jest on obcięty licznymi uskokami tektonicznymi, a i w swojej wewnętrznej budowie charakteryzuje się przebiegiem licznych dyslokacji tektonicznych. Są one głównie efektem działania odprężających sił w obrębie tej płyty, która z jednej strony jest erozyjnie podcinana przez okoliczne potoki, a z drugiej strony izolowane w ten sposób bloki wapieni ulegają grawitacyjnemu zapadaniu się w plastyczne podłoże zbudowane z miękkich łupków środkowojurajskich. Główna część wąwozu zbudowana jest ze środkowojurajskich (bajos) białych wapieni krynoidowych tzw. formacji wapienia ze Smolegowej, których miąższość dochodzi tutaj do 100 metrów (Fig. 13). Wapienie te są przykryte niewielkiej miąższości czerwonymi wapieniami krynoidowymi (formacja wapienia z Krupianki) oraz czerwonymi wapieniami bulastymi facji Ammonitico Rosso (formacja wapienia czorsztyńskiego). Wszystkie wymienione utwory należą do sukcesji czorsztyńskiej (Birkenmajer, 1970, 1977). Na nie nasunięte są, w postaci spektakularnego fałdu Czajakowej Skały obalonego ku północy, utwory sukcesji niedzickiej, które w postaci lokalnej płaszczowiny leżą na poziomej płycie wapiennej bloku Homoli. Sekwencja utworów płaszczowiny niedzickiej jest zbliżona do profilu sukcesji czorsztyńskiej (Fig. 13) z wyjątkiem środkowej jej części z jednej strony [gdzie występują górnojurajskie (oksford) utwory krzemionkowe - radiolaryty, nieobecne w profilu sukcesji czorsztyńskiej] a z drugiej strony wyraźną dysproporcją w miąższości środkowojurajskich wapieni krynoidowych. Profil tej sukcesji rozpoczynają ciemne utwory jury środkowej, występując w grupie Czajakowej Skały, gdzie tworzą spąg nasunięcia płaszczowiny niedzickiej na jednostkę czorsztyńską. Zwłaszcza czarne łupki sferosyderytowe były podatne na takie tektoniczne przemieszczenia, a dzisiaj powodują tworzenie się osuwisk strukturalnych, czego najlepszym przykładem jest polana pod Czajakową Skałą, gdzie łupki te znajdują się w najniższej części jednego z najlepiej widocznych osuwisk. W sukcesji tej wapienie krynoidowe są niewielkiej miąższości a przykryte czerwonymi wapieniami bulastymi. Te drugie dostarczyły bogatej fauny amonitów, na podstawie których precyzyjnie ustalono ich wiek na bajos-oksford (jura środkowa-jura górna). Wapienie te najlepiej odsłaniają się w głównej skałce Czajakowej Skały (Birkenmajer, 1970, 1979; Wierzbowski et al., 1999). Radiolaryty stanowią najbardziej charakterystyczny wyróżnik litologiczny dla sukcesji niedzickiej, świetnie widoczny w samym jądrze obalonego fałdu (Birkenmajer, 1970, 1979; Jurewicz, 1994; Golonka \& Krobicki, 2001). Formacja ta składa się z trzech ogniw (Birkenmajer, 1977) (w następstwie stratygraficznym): czerwone radiolaryty, zielone radiolaryty i ponownie czerwone radiolaryty formacji radiolarytów z Czajakowej, które tutaj mają swój stratotyp (Fig. 12, 13). Są to cienkouławicone (od kilku do $20 \mathrm{~cm}$ miąższości - por. Fig. 12D) utwory rogowców i wapieni krzemionkowych przeławicanych cienkimi łupkami o grubościach nieprzekraczających $2 \mathrm{~cm}$. Leżące ponad radiolarytami czerwone wapienie bulaste i cienkouławicone mikrytowe wapienie kalpionellowe są wieku górnojurajsko-dolnokredowego, a ponad nimi niewielkiej miąższości jasnopopielate wapienie mikrytowe z rogowcami, które wieńczą profil utworów dolnej kredy. Wiekowo wapienie te odpowiadają wapieniom rogowcowym formacji wapienia pienińskiego znanym z centralnej części Pienin (patrz wyżej - spektakularne strome szczyty Trzech Koron, Sokolicy, Mnichów) (Fig. 11).

Natomiast najstarsze utwory sukcesji czorsztyńskiej odsłaniające się w południowej części bloku Homoli jak i w korycie sąsiadującego od zachodu potoku Krupianka (Fig. 14), reprezentowane są przez szare lub szarobrunatne margle i wapienie margliste plamiste oraz czarne lupki ze sferosyderytami (odpowiednio formacja margli z Krempachów i formacja łupków ze Skrzypnego) (aalen-najniższy bajos) (ekwiwalenty facjalne czarnych łupków obserwowanych w osuwisku pod Czajakową Skałą). W odniesieniu do geologii alpejskiej można zaklasyfikować te utwory do szeroko rozprzestrzenionej w całym łańcuchu alpejskim facji Fleckenkalk/Fleckenmergel (= plamiste wapienie/margle). Paleośrodowiskowo utwory te reprezentują niedotlenione (redukcyjne) warunki środowiska sedymentacji we wczesnym etapie rozwoju basenu pienińskiego.

\section{References (Literatura)}

Alexandrowicz, Z. \& Alexandrowicz, S.W., 2004. Geoparks - the most valuable landscape parks in southern Poland. Polish Geological Institute, Special Paper, 13: 49-56.
Aubrecht, R. \& Túnyi, I., 2001. Original orientation of neptunian dykes in the Pieniny Klippen Belt (Western Carpathians): the first results. Contributions to Geophysics and Geodesy, 31: 557-578. 
Baumgart-Kotarba, M., 1996. On origin and age of the Orava Basin, West Carpathians. Studia Geomorphologica Carpatho-Balcanica, 30: 101-116.

Baumgart-Kotarba, M., 2001. Continuous tectonic evolution of the Orava basin from Late Badenian to the present-day. Geologica Carpathica, 52: $103-110$

Bąk, K., 2000. Biostratigraphy of deep-water agglutinated Foraminifera in Scaglia Rossa-type deposits of the Pieniny Klippen Belt, Carpathians, Poland. In: Hart, M.B., Kaminski, M.A. \& Smart, C.W. (Eds.): Proceedings of the Fifth International Workshop on Agglutinated Foraminifera. Grzybowski Foundation Special Publication, 7: 15-41, Kraków.

Birkenmajer, K., 1958. Submarine erosional breaks and Late Jurassic synorogenic movements in the Pieniny Klippen Belt geosyncline. Bulletin de Academie Polonaise de Science, Sér., sci. chim., géol. \& géogr., 8: 551-558.

Birkenmajer, K., 1963. Stratigraphy and paleogeography of the Czorsztyn Series (Pieniny Klippen Belt, Carpathians) in Poland. Studia Geologica Polonica, 9: 1-380. (In Polish, English summary)

Birkenmajer, K., 1970. Pre-Eocene fold structures in the Pieniny Klippen Belt (Carpathians) of Poland. Studia Geologica Polonica, 31: 1-77. (In Polish, English summary)

Birkenmajer, K., 1975. Tectonic control of sedimentation at the JurassicCretaceous boundary in the Pieniny Klippen Belt, Carpathians. Colloque sur la limite Jurass.-Crét., Lyon-Neuchâtel (1973). Mémoire BRGM: 294-299.

Birkenmajer, K., 1977. Jurassic and Cretaceous lithostratigraphic units of the Pieniny Klippen Belt, Carpathians, Poland. Studia Geologica Polonica, 45: 1-158.

Birkenmajer, K., 1979. Przewodnik geologiczny po pienińskim pasie skatkowym. Wydawnictwa Geologiczne, 1-237, Warszawa. (In Polish only)

Birkenmajer K., 1983. Strike-slip faults in the northern boundary zone of the Pieniny Klippen Belt, Carpathians. Studia Geologica Polonica, 77: 89-112. (In Polish, English summary)

Birkenmajer, K., 1986. Stages of structural evolution of the Pieniny Klippen Belt, Carpathians. Studia Geologica Polonica, 88: 7-32

Birkenmajer, 2003. Post-collisional Late Middle Miocene (Sarmatian) Pieniny Volcanic Arc, Western Carpathians. Bulletin of the Polish Academy of Sciences, Earth Sciences, 51, 1: 79-89.

Birkenmajer, K., 2006. Dunajec River Gorge, Pieniny Mts, West Carpathians. Pieniny - przyroda i człowiek, 9: 9-22. (In Polish, English summary)

Birkenmajer, K., Bąk, M. \& Bąk, K., 2001. Stop C5.3 - Sromowce Niżne - Trzy Korony Mt. In: Birkenmajer, K. \& Krobicki, M. (Eds.): $12^{\text {th }}$ meeting of the Association of European Geological Societies; 10-15 September 2001, Kraków: Carpathian palaeogeography and geodynamics: a ultidisciplinary approach; field trip guide. Polish Geological Institute, Kraków: 146-150

Cieszkowski, M. \& Golonka, J., 2005. Olistolites and olistostromes as geotouristic objects - examples from Northern Carpathians, Poland. In: Doktor, M. \& Waśkowska-Oliwa, A. (Eds.): Geotourism-new dimensions in XXI century tourism and chances for future development. 2nd International Conference Geotour 2005, 22-24 September, Kraków: 21-23.

Cieszkowski, M. \& Golonka, J., 2006. Olistostrom as indicators of the geodynamic process (Northern Carpathians). Geolines, 20: 27-28.

Cieszkowski, M., Golonka, J., Krobicki, M., Ślączka A., Oszczypko, N. \& Waśkowska-Oliwa, A., 2008. The Northern Carpathians plate tectonic evolutionary stages and origin of olistolites. In: Németh, Z. \& Plašienka, D. (Eds.): SlovTec 08, $6^{\text {th }}$ Meeting of the Central European Tectonic Studies Group (CETeG) \& $13^{\text {th }}$ Meeting of the Czech Tectonic Studies Group (ČTS), 23-26 April 2008, Upohlav, Pieniny Klippen Belt, Slovakia. Proceedings and Excursion Guide: 21-22

Ghibaudo, G., 1992. Subaqueous sediment gravity flow deposits: practical criteria for their field description and classification. Sedimentology, 39: 423-454.

Golonka, J., 2000. Cambrian-Neogene Plate Tectonic Maps. Wydawnictwa Uniwersytetu Jagiellońskiego, Kraków, 125 pp.

Golonka, J., 2004. Plate tectonic evolution of the southern margin of Eurasia in the Mesozoic and Cenozoic. Tectonophysics, 381: 235-273.

Golonka, J., 2005. Mesozoic plate tectonics of the Inner Carpathians - rotational approach. Geolines, 19: 42-43.

Golonka, J., 2007a. Late Triassic and Early Jurassic palaeogeography of the world. Palaeogeography, Palaeoclimatology, Palaeoecology, 244, 1-4: 297-307.
Golonka, J., 2007b. Phanerozoic paleoenvironment and paleolithofacies maps. Mesozoic. Kwartalnik AGH, Geologia, 33, 2: 211-264.

Golonka, J. \& Krobicki, M., 2001. Upwelling regime in the Carpathian Tethys: a Jurassic-Cretaceous palaeogeographic and palaeoclimatic perspective. Geological Quarterly, 45: 15-32.

Golonka, J. \& Krobicki, M., 2004. Jurassic paleogeography of the Pieniny and Outer Carpathian basins. Rivista Italiana di Paleontologica Stratigrafica, 110: 5-14.

Golonka, J. \& Krobicki, M., 2006. Field trip A - From Tethyan to Platform Facies. Outer Carpathians. In: Wierzbowski, A., Aubrecht., R., Golonka, J., Gutowski, J., Krobicki, M., Matyja, B.A, Pieńkowski, G. \& Uchman, A. (Eds.): Jurassic of Poland and adjacent Slovakian Carpathians. Field trip guidebook. 7th International Congress on the Jurassic System, 6-18 September 2006, Kraków, Poland. pp. 11-15.

Golonka, J. \& Krobicki, M., 2007. Dunajec River rafting as one of the most important geotouristic object of the future trans-bordering PIENINY Geopark. Geoturystyka, 3 (10): 29-44.

Golonka, J. \& Rączkowski, W., 1984. Arkusz Piwniczna; Detailed Geological Map of Poland; Geological Institute - Publishing House Wydawnictwa Geologiczne. 85 p. Warszawa.

Golonka, J. \& Sikora, W., 1981. Microfacies of the Jurassic and Lower Cretaceous sedimentarily thinned deposits of the Pieniny Klippen Belt in Poland. Biuletyn Instytutu Geologicznego, 31: 7-37. (In Polish, English summary)

Golonka, J., Krobicki, M., Oszczypko, N., Ślączka, A. \& Słomka, T., 2003. Geodynamic evolution and paleogeography of the Polish Carpathians and adjacent areas during Neo-Cimmerian and preceding events (latest Triassic-earliest Cretaceous). In: McCann, T. \& Saintot, A. (Eds.): Tracing Tectonic Deformation Using the Sedimentary Record. Geological Society, Special Publication, London, 208: 138-158.

Golonka, J., Gahagan, L., Krobicki, M., Marko, F., Oszczypko, N. \& Ślączka, A., 2006. Plate-tectonic evolution and paleogeography of the CircumCarpathian region. In: Golonka, J. \& Picha, F.J. (Eds.): The Carpathians and their foreland: Geology and hydrocarbon resources. American Association of Petroleum Geologists, Memoire, 84: 11-46.

Grabowski, J., Krobicki, M. \& Sobień, K., 2008. New palaeomagnetic results from the Polish part of the Pieniny Klippen Belt, Carpathians - evidence for the palaeogeographic position of the Czorsztyn Ridge in the Mesozoic. Geological Quarterly, 52, 1: 31-44.

Jurewicz, E., 1994. Structural analysis of the Pieniny Klippen Belt at Jaworki, Carpathians, Poland. Studia Geologica Polonica, 7-87. (In Polish, English summary)

Jurewicz, E., 1997. The contact between the Pieniny Klippen Belt and Magura Unit (the Małe Pieniny Mts.). Geological Quarterly, 41, 3: 315-326.

Jurewicz, E., 2005. Geodynamic evolution of the Tatra Mts. and the Pieniny Klippen Belt (Western Carpathians): problems and comments. Acta Geologica Polonica, 3: 295-338.

Kováč, M., Nagymarosy, A., Oszczypko, N., Ślączka, A., Csontos, L., Marunteanu, M., Matenco, L. \& Márton. M., 1998. Palinspastic reconstruction of the Carpathian-Pannonian region during the Miocene. In: Rakús, M. (Ed.): Geodynamic development of the Western Carpathians. Geological Survey of Slovac Republic, Bratislava: 189-217.

Krobicki, M., 1996. Neo-Cimmerian uplift of intraoceanic Czorsztyn pelagic swell (Pieniny Klippen Belt, Polish Carpathians) indicated by the change of brachiopod assemblages. In: Riccardi A.C. (Ed.): Advances in Jurassic Research. GeoResearch Forum, 1-2: 255-264, Zurich.

Krobicki, M., 2006. Field trip A - From Tethyan to Platform Facies. Outer Carpathians. Stop A5 - Falsztyn - Czorsztyn Succession (AalenianBajocian). In: Wierzbowski, A., Aubrecht., R., Golonka, J., Gutowski, J., Krobicki, M., Matyja, B.A, Pieńkowski, G. \& Uchman, A. (Eds.): Jurassic of Poland and adjacent Slovakian Carpathians. Field trip guidebook. $7^{\text {th }}$ International Congress on the Jurassic System, 6-18 September 2006, Kraków, Poland. pp. 39-41.

Krobicki, M. \& Golonka, J., 2006. Pieniny Klippen Belt. In: Wierzbowski, A., Aubrecht, R., Golonka, J., Gutowski, J., Krobicki, M., Matyja, B.A, Pieńkowski, G. \& Uchman, A. (Eds.): Jurassic of Poland and adjacent Slovakian Carpathians. Field trip guidebook. 7th International Congress on the Jurassic System, 6-18 September 2006, Kraków, Poland. pp. 15-22.

Krobicki, M., Poprawa, P. \& Golonka, J., 2006. Early Jurassic - Late Cretaceous evolution of the Pieniny Klippen Basin indicated by tectonic subsidence analysis. In: Oszczypko, N., Uchman, A. \& Malata, E. (Eds.):Palaeotectonic evolution of the Outer Carpathian and Pieniny Klippen Belt Basins. Instytut Nauk Geologicznych UJ: 165-178. Kraków. (In Polish only) 
Krobicki, M. \& Słomka, T., 1999. Berriasian submarine mass movements as results of tectonic activity in the Carpathians basins. Geologica Carpathica, 50: 42-44.

Krobicki, M. \& Wierzbowski, A., 2004. Stratigraphic position of the Bajocian crinoidal limestones and their palaeogeographic significance in evolution of the Pieniny Klippen Basin. Tomy Jurajskie, 2: 69-82. (In Polish, English summary)

Książkiewicz, M., 1977. The Tectonics of the Carpathians. In: Geology of Poland, Volume 4. Tectonics (ed. Pożaryski, W.), 476-699.Wydawnictwa Geologiczne, Warszawa.

Lewandowski, M., Krobicki, M., Matyja., B.A. \& Wierzbowski, A., 2005. Palaeogeographic evolution of the Pieniny Klippen Basin using stratigraphic and palaeomagnetic data from the Veliky Kamenets section (Carpathians, Ukraine). Palaeogeography, Palaeoclimatology, Palaeoecology, 216: 53-72.

Lowe, D.R., 1997. Reinterpretation of depositional processes in a classic flysch sequence (Pennsylvanian Jackfork Group), Ouachita Mountains, Arkansas and Oklahoma: discussion: American Association of Petroleum Geology Bulletin, 81, 3: 460-465.

Mišík, M., 1999. Contribution to the lithology and paleogeography of radiolarites in the Western Carpathians. Mineralia Slovaca, 31: 491-506.

Michalík, J. \& Reháková, D., 1995. Sedimentary records of Early Cretaceous tectonic activity in the Alpine-Carpathian region. Slovak Geological Magazine, 2: 159-164.

Mutti, E. \& Normark, W.R., 1987. Comparing examples of modern and ancient turbidite systems: problems and concepts. In: Legget, J.K. \& Zuffa, G.G. (Eds): Marine Clastic Sedimentology, concepts and case studies: Graham \& Trotman, London, 1-38.

Mutti, E. \& Ricci Lucchi, F., 1975. Turbidite facies and facies associations. In: Mutti, E. et al., (Eds): Examples of turbidite facies associations from selected formations of the Northern Apennines. Field Trip A11, IX Int. Sedimentol. Congr., Nice, 21-36.

Oszczypko, N., 2004. The structural position and tectonosedimentary evolution of the Polish Outer Carpathians. Przeglad Geologiczny, 52 , 8/2: 780-791.

Oszczypko, N., 2006a. Late Jurassic-Miocene evolution of the Outer Carpathian fold-and-thrust belt and its foredeep basin (Western Carpathians, Poland). Geological Quarterly, 50, 1: 169-194.

Oszczypko, N., 2006b. Position of the Polish Outer Carpathians in the Alpine arc and their stages of development. In: Oszczypko, N., Uchman, A. \& Malata, E. (Eds.): Palaeotectonic evolution of the Outer Carpathian and Pieniny Klippen Belt Basins. Instytut Nauk Geologicznych UJ: 9-18. Kraków. (In Polish, English summary)

Oszczypko, N. \& Oszczypko-Clowes, M., 2006. Evolution of the Magura Basin. In: Oszczypko, N., Uchman, A. \& Malata, E. (Eds.): Palaeotectonic evolution of the Outer Carpathian and Pieniny Klippen Belt Basins. Instytut Nauk Geologicznych UJ: 133-164. Kraków. (In Polish, English summary)

Oszczypko, N., Oszczypko-Clowes, M., Golonka, J. \& Marko, F., 2005. Oligocene-Lower Miocene sequences of the Pieniny Klippen Belt and adjacent Magura Nappe between Jarabina and the Poprad River (East Slovakia and South Poland): their tectonic position and palaeogeographic implications. Geological Quarterly, 49, 4: 379-402.

Plašienka, D., 2002. Early stages of tectonic evolution of the Pieniny Klippen Belt. GeoLines, 14: 75-78.

Plašienka, D., Grecula, P., Putiš, M., Kováč, M. \& Hovorka, D. 2000. Evolution and structure of the Western Carpathians: an overview. In: Grecula, P., Hovorka, D. \& Putiš, M. (Eds.): Geological evolution of the Western Carpathians, Geocomplex. Bratislava, pp. 1-24

Pszczółkowski, 1987. Paleogeography and paleotectonic evolution of Cuba and adjoining areas during the Jurassic-Early Cretaceous. Annales Societatis Geologorum Poloniae, 57: 27-142.

Reading, H.G. \& Richards. M., 1994. Turbidite systems in deep-water basin margins classified by grain size and feeder system. American Association of Petroleum Geology Bulletin, 78, 5: 792-822.
Săndulescu, M., 1988. Cenozoic Tectonic History of the Carpathians, In: Royden L. \& Horváth F. (Eds.): The Pannonian Basin: A study in basin evolution. American Association of Petroleum Geology, Memoire, 45: 17-25, Tulsa.

Schlögl, J., Rakús, M., Krobicki, M., Matyja, B.A., Wierzbowski, A., Aubrecht, R., Sitár, V. \& Józsa, Š., 2004. Beňatina Klippe - lithostratigraphy, biostratigraphy, palaeontology of the Jurassic and Lower Cretaceous deposits (Pieniny Klippen Belt, Western Carpathians, Slovakia). Slovak Geological Magazine, 10, 4: 241-262.

Shanmugam, G., 2000. 50 years of turbidite paradigm (1950s-1990s): deepwater processes and facies models - a critical perspective. Marine Petroleum Geology, 17: 285-342.

Słomka, T., 1986. Statistical approach to study of flysch sedimentation Kimmeridgian-Hauterivian Cieszyn Beds, Polish Outer Carpathians. Annales Societatis Geologorum Poloniae, 56: 227-336. (In Polish, English summary)

Stow, D.A.V., 1986. Deep clastic seas. In: Reading, H.G., (Ed.), Sedimentary environments and facies, Blackwell Scientific, Oxford, 399-444.

Ślączka, A., 1996. Oil and gas in the northern Carpathians. In: Wessely, G. \& Liebl, W., (Eds.): Oil and gas in Alpidic thrustbelts and basins of Central and Eastern Europe, Eur. Ass. Geosci. Engin., Sp. Publ., 5: 187195. Geological Society, London.

Tłuczek, D., 2004. Pozycja geologiczna paleogeńskich wapieni organogenicznych oraz zlepieńców i piaskowców organodetrytycznych rejonu Lipnika (Pieniny na poludnie od Szczawnicy-kartowanie detaliczne, mikrofacje, aspekt geoturystyczny). Unpublished Mr. Thesis. Archiwum ING UJ., 129 pp. (In Polish only)

Tyszka, J., 1994. Response of Middle Jurassic benthic foraminiferal morphogroups to disoxic/oxic conditions in the Pieniny Klippen Basin, Polish Carpathians. Palaeogeography, Palaeoclimatology, Palaeoecology, 110: $55-81$.

Tyszka, J., 2001. Microfossil assemblages as bathymetric indicators of the Toarcian/Aalenian „Fleckenmergel”-facies in the Carpathian Pieniny Klippen Belt. Geologica Carpathica, 52: 147-158.

Vanko, J., 1988. Mapa recentných vertikálnych pohybov Západných Karpát na Slovensku ore epochu 1952-1977. Geodetický a kartografický obzor, Bratislava, 34/76: 216-222. (In Slovak only)

Vass, D., 1998. Neogene geodynamic development of the Carpathian arc and associated basins. In: Rakús, M., (Ed.): Geodynamic development of the Western Carpathians. Geological Survey of Slovac Republic, Bratislava, Dionýz Štúr Publishers: 155-158.

Wieczorek, J., 1988. Maiolica - A unique facies of the Western Tethys. Annales Societatis Geologorum Poloniae, 58: 255-276.

Wierzbowski, A., Jaworska, M. \& Krobicki, M., 1999. Jurassic (Upper Bajocian-lowest Oxfordian) ammonitico rosso facies in the Pieniny Klippen Belt, Carpathians, Poland: its fauna, age, microfacies and sedimentary environment. Studia Geologica Polonica, 115: 7-74.

Wierzbowski, A., Aubrecht, R., Krobicki, M., Matyja, B.A. \& Schlögl, J., 2004. Stratigraphy and palaeogeographic position of the Jurassic Czertezik Succession, Pieniny Klippen Belt (Western Carpathians) of Poland and Eastern Slovakia. Annales Societatis Geologorum Poloniae, 74: 237-256.

Zuchiewicz, W., 1982. Geneza przełomu Dunajca przez Pieniny. Wszechświat, 83 (10-11): 169-173. (In Polish only)

Zuchiewicz, W., Tokarski, A.K., Jarosiński, M. \& Márton, E., 2002. Late Miocene to present day structural development of the Polish segment of the Outer Carpathians. EGU Stephen Mueller Special Publication Series, 3: 185-202.

Żytko, K., Zając, R., Gucik, S., Ryłko, W., Oszczypko, N., Garlicka, I., Nemčok, J., Eliáš, M., Menčik, E. \& Stránik, Z., 1989. Map of the tectonic elements of the Western Outer Carpathians and their foreland. In: Poprawa, D. \& Nemčok, J. (Eds.): Geological Atlas of the Western Outer Carpathians and their Foreland. Państwowy Instytut Geologiczny, Warszawa/GUDŠ Bratislava/Uug Praha. 